$1-1-1966$

\title{
Twice-weekly milk delivery : experience, opinions, and economic effects
}

James H. Clarke

Charles N. Shaw

Adrian L. Haught

Follow this and additional works at: https://researchrepository.wvu.edu/ wv_agricultural_and_forestry_experiment_station_bulletins

\section{Digital Commons Citation}

Clarke, James H.; Shaw, Charles N.; and Haught, Adrian L., "Twice-weekly milk delivery : experience, opinions, and economic effects" (1966). West Virginia Agricultural and Forestry Experiment Station Bulletins. 525T.

https://researchrepository.wvu.edu/wv_agricultural_and_forestry_experiment_station_bulletins/665 @ WVU. It has been accepted for inclusion in West Virginia Agricultural and Forestry Experiment Station Bulletins by an authorized administrator of The Research Repository @ WVU. For more information, please contact ian.harmon@mail.wvu.edu. 
West Virginia University Libraries

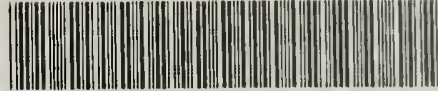

308021009521334 


\section{Digitized by the Internet Archive in 2010 with funding from \\ Lyrasis Members and Sloan Foundation}




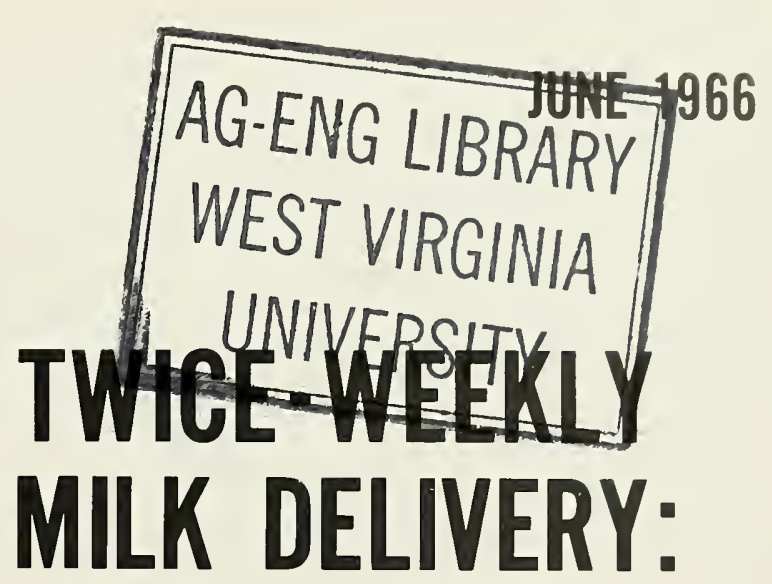

Experience,

Opinions, and

Economic Effects

WEST VIRGINIA UNIVERSITY AGRICULTURAL EXPERIMENT STATION 


\section{The Authors}

Jas. H. Clarke is Agricultural Economist, Adrian L. Haught was formerly Graduate Research Assistant, and Charles N. Shaw was formerly Research Assistant for the West Virginia University Agricultural Experiment Station.

\section{Acknowledgments}

The authors express their appreciation to personnel of the Johnson's All Star Dairy of Ashland, Kentucky, and of the Cloverdale Dairy and Garvin's Jersey Farm Dairy of Wheeling, West Virginia, without whose help this study would not have been possible. They also acknowledge the assistance of Thomas R. Whelan who conducted the field interviews among the milk distributors and assisted with the analysis of their retail milk delivery operations and of their opinions pertaining to twice-weekly milk delivery.

This study was part of Northeast Regional Research Project NEM-25, "Adapting Milk Distribution Systems and Practices to Changing Conditions," and was supported, in part, by Regional Research Funds.

West ViRginia UNIVERSITY Agricultural Experiment Station College of Agriculture and Forestry

A. H. Vanlandingham, Director 


\section{TWICE-WEEKLY}

MILK DELIVERY:

Experience, Opinions, and Economic Effects

Jas. H. Clarke

Adrian L. Haught

Charles N. Shaw 


\section{Conclusions}

It was concluded that there was no significant difference in the quantity of home-delivered products purchased by the continuous customers during the year of the twice-weekly delivery service (1959), and the quantity purchased during the years in which three deliveries per week were offered (1958 and 1960). Thus, the dealer did not lose a significant amount of sales to these customers when he converted to twice-weekly delivery service. Other changes in the market and within the company itself made a complete analysis of the effect of a twice-aweek delivery on the company's operations impractical, if not impossible.

Based upon previous delivery cost studies, a savings of one to one and three-tenths cents per unit due to a reduced frequency of delivery could have been realized.

The preceding amounts were determined as possible savings to the dealer; thus, he could benefit through increased profit. The consumers could benefit through reduced prices, the routemen could benefit through increased wages, or they all could benefit through some combination of the above, which would be determined by the competitive forces within the market at any particular time.

It appears that the most frequently mentioned reason (lack of freshness) given by route customers for refusing less frequent delivery may have been invalid. These opinions were thought to be based partially on the customers' experiences with milk keeping quality during past decades, when the processing, refrigeration, and handling was not so adequate as it is today. A higher proportion of respondents over 55 years than under 55 years of age gave "lack of freshness" as the reason for non-acceptance. This difference was statistically significant. Actually, only a small portion of the retail route customers had experienced difficulty with milk keeping quality at any time during the year preceding the interview. Other studies of keeping quality also support the view that keeping quality is not a problem.

The distributors' primary reason for being opposed to twice-a-week delivery was the customers' lack of storage space. This view likewise appears to be invalid since 93 per cent of the customers interviewed would be able to store their current delivery volumes should these have been delivered on a twice-a-week basis.

Probably there would be a definite saving to consumers, dealers, or both, by reducing the number of milk deliveries per week. This step would aid the milk industry to preserve the home delivery system of milk distribution. Herein lies one solution to making home-delivered milk prices more competitive with prices of milk sold in stores. 


\section{Contents}

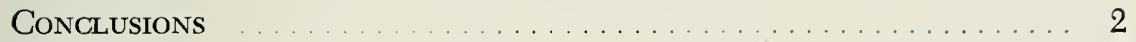

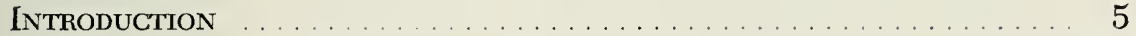

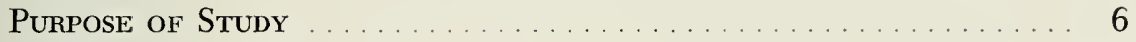

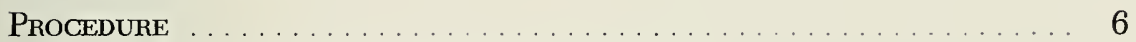

Experience With Twice-a-Week Delivery ............ 7

Consumer Attitudes and Opinions $\ldots \ldots \ldots \ldots \ldots \ldots \ldots .7$

Distributor Attitudes and Opinions $\ldots \ldots \ldots \ldots \ldots \ldots \ldots$

Analysis of Experience With Twice-Weekly Retail Delivery . . . 7

Fluid Milk Sales ............................ 9

Price Influence $\ldots \ldots \ldots \ldots \ldots \ldots \ldots \ldots \ldots \ldots \ldots \ldots$

Total Revenue From Sales .................... 16

Analysis of Additional Product Sales $\ldots \ldots \ldots \ldots \ldots \ldots \ldots$

Analysis of Combined Product Sales .................. 21

Analysis of Consumer Attitudes and Opinions $\ldots \ldots \ldots \ldots \ldots \ldots 22$

Additional Deliveries . . . . . . . . . . . . . . . 22

Customers' Attitudes . . . . . . . . . . . . . . . . . . . . 23

Payment for Home Delivery ..................... 24

Twice-Weekly Milk Delivery Not Acceptable ............. 24

Reasons for Non-Acceptance . . . . . . . . . . . . . . . 25

Fresh Fluid Milk Desired . . . . . . . . . . . . . . . . . . . 29

Storage Space Analysis . . . . . . . . . . . . . . . . . . . 29

Amount of Storage Versus Acceptance .............. 31 


\section{CONTENTS (Continued)}

Other Factors Affecting Acceptance .................. 31

Family Size ......................... 31

Number of Children in Family . . . . . . . . . . . . . . 32

Quantity of Milk Delivered ................... 33

Weekly Family Income . . . . . . . . . . . . . . . . . . . 33

Milk Keeping Quality Adequate ........................ 34

Respondents' Experience With Milk Keeping Quality ..... 35

Market Comparison ......................... 38

Analysis of Distributor Attitudes and Opinions . . . . . . . . . . 39

Retail Route Sales Declining ...................... 39

Reasons for Decline .......................... 40

Characteristics of Retail Routes ....................41

General Delivery Practices ................... 41

Frequency and Volume of Delivery to Customers ....... 42

Distance Traveled Per Route . . . . . . . . . . . . . . 44

Attitudes Concerning Reduced Delivery Service ........... 44

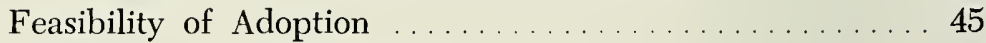

Feasibility of Partial Adoption ..................45

Twice-Weekly Delivery Not Planned .................. 47

Suggestions to Reduce Delivery Costs . . . . . . . . . . . . 47

Analysis of Retall Delivery Costs $\ldots \ldots \ldots \ldots \ldots \ldots \ldots \ldots$

ECONOMIC IMPLICATIONS $\ldots \ldots \ldots \ldots \ldots \ldots \ldots \ldots \ldots \ldots \ldots \ldots$

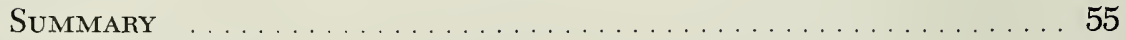

The Problem .............................. 55

Experience With Twice-Weekly Delivery ............. 55

Consumer Attitudes and Opinions . . . . . . . . . . . . . 57

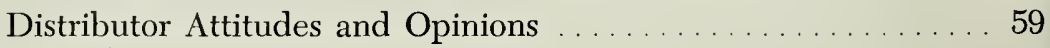




\section{Twice-Weekly Milk Delivery: Experience, Opinions, and Economic Effects}

By Jas. H. Clarke, Adrian L. Haught, and Charles N. Shaw

PRIOR TO WORLD WAR II, daily retail delivery of milk was commonly practiced by milk distributors throughout the United States. Daily delivery on retail milk routes was prohibited during the war by the Office of Defense Transportation. This was done to conserve vehicles, gasoline, rubber, and manpower. This led to every-other-day delivery, which was economically more efficient than daily delivery. More milk was distributed in less time, labor productivity per man hour was increased, and truck maintenance costs were lowered.

Following the war, the practice of every-other-day delivery was continued on a voluntary, industry-wide basis, and has been modified to three deliveries per week during the last fifteen years. These steps away from daily delivery have been important in keeping delivery costs down.

However, there is a continuous need for change in the milk industry if it is to keep pace with the progressing economy. Also, labor pressures for a shorter work week have suggested the desirability for less frequent delivery of milk.

The patterns of fluid milk distribution have been changing during the past twenty years. The proportion of dealers' sales of fluid milk sold on regular retail home-delivery routes has decreased, while the proportion of sales marketed at wholesale outlets has increased. The extent of the change has varied widely from market to market.

In the New York marketing area the sale of fluid milk on retail routes, as a proportion of total sales, decreased from 30 per cent in 1949 to only 24 per cent in 1955 . Wholesale distribution, as a proportion of total sales, increased by a corresponding amount during the same period. In the St. Louis marketing area retail sales decreased from 54 per cent of total sales in 1945 to 43 per cent in 1954. In the Minneapolis-St. Paul marketing area retail sales decreased from 48 per cent of total sales in 1950 to 43 per cent in $1954 .^{1}$

The changes in marketing patterns are due to many factors, especially price differentials between home-delivery and store purchases, Some milk distributors emphasize the wholesale market, while others 
emphasize retail sales. Many chain stores offer milk as a preferred item of trade, while carrying a diversified line of dairy products along with the milk. Also, improved roads and transportation have made these stores more readily accessible to consumers. ${ }^{2}$

Unless retail milk delivery continues to become more efficient, it may be priced out of the available market and be replaced by wholesale distribution. Data from one study showed that approximate costs per quart were as follows: assembly, 1.2 cents; processing, 4.4 cents, and distribution, 5.6 cents. ${ }^{3}$ If limited to retail distribution, costs per quart would be even higher.

The cost to the dealer is greater for distributing milk, especially by retail delivery, than either the cost of assembling or the cost of processing the milk. Thus, distribution cost is one area which must be considered by any dealer who is attempting to increase the efficiency of retail home delivery of milk. Since a large portion of distribution cost consists of labor cost and truck cost, these two items must be considered fully in any efficiency study on retail home delivery of milk. One method of reducing labor cost and truck cost is to reduce the frequency of delivery.

\section{Purpose of Study}

The purpose of this study was fourfold. First, to determine if reducing the frequency of delivery from three times a week to twice a week had any significant effect upon the quantity of products delivered to retail milk route customers. Second, to discover route customer attitudes and opinions concerning reduced delivery frequency. Third, to discover milk distributor attitudes, opinions, and plans concerning twice-a-week delivery. And fourth, to determine the relative cost of delivery, per unit, as related to frequency of delivery.

\section{Procedure}

Several milk distributors in West Virginia were interviewed in the early stages of the study concerning the feasibility of twice-a-week milk delivery. During this phase of the study, it was discovered that Johnson's All Star Dairy Company in nearby Ashland, Kentucky, had provided twice-a-week delivery to its retail milk route customers during approximately a one-year period ending in May, 1960. The company had later discontinued this delivery policy due to competitive factors. However, microfilmed records of sales to retail route customers were made available for study to research personnel of the West Virginia University Agricultural Experiment Station.

${ }^{3}$ U.S.D.A., Marketing Costs and Margins for Fresh Milk, Agricultural Marketing Service, Misc. Pub. 733, Rev., Feb., 1959. 


\section{Experience with Twice-a-Week Delivery}

The purchases of all home-delivery customers served by this dairy were then tabulated for one complete week in October, for each of the three years 1958, 1959, and 1960. The data were later classified according to whether the customer purchased milk on a home-delivery basis during one, two, or all three of the years examined.

The week in October was selected since it occurred at approximately the mid-point of the period in which twice-a-week delivery was provided. The selection of the corresponding calendar week in each of the three years also provided a valid basis for comparison. The chance of bias due to summer vacations and school holidays was largely removed by the selection of the week in October.

\section{Consumer Attitudes and Opinions}

A study of customers' reactions to twice-a-week delivery was made in two areas: one, in Ashland, Kentucky, where twice-a-week delivery had been tried, and two, in Wheeling, West Virginia, a city of similar size and with similar industries, where three deliveries of milk per week were provided for retail milk route customers.

The customers interviewed were selected by means of a systematic sample from a list of names of all retail route customers served by Johnson's All Star Dairy in Ashland and by the Cloverdale Dairy and Garvin's Dairy in Wheeling. Every fifth customer was selected for interview after determination of the first interviewee was chosen at random. The total number of interviews conducted in Ashland was 504 and in Wheeling, 500. The interviews were conducted in July and August, 1961.

\section{Distributor Attitudes and Opinions}

In February and March, 1963, representatives of 53 milk distributors in West Virginia were interviewed. Of these, 47 represented milk processor-distributors and 6 represented producer-processor distributors. Representatives of all but a few of the dairies in the State that provided retail delivery to homes were interviewed, and those not included were dealers known to have relatively small-volume operations and two were not available for interview at the time the survey was made.

\section{Analysis of Experience With Twice-Weekly Retail Milk Delivery}

Records were extracted for all customers who received home delivery of milk from Johnson's All-Star Dairy in Ashland, Kentucky, during any or all of the three years examined. The records were then tabulated, and the customers were classified as either one-year, two-year, or threeyear customers, based upon the number of years that they had received home delivery during the time period examined. 
Table 1. Number and Quantity of Fluid Milk Purchases on Home Delivery Routes, by Duration of Purchase, Johnson's Dairy, Ashland, KeNTUCKY, 1958, 1959, AND 1960

\begin{tabular}{|c|c|c|c|c|c|c|}
\hline \multirow{2}{*}{$\begin{array}{l}\text { No. of Years } \\
\text { Purchased }\end{array}$} & \multicolumn{2}{|c|}{1958} & \multicolumn{2}{|c|}{1959} & \multicolumn{2}{|c|}{1960} \\
\hline & Purchases & $\begin{array}{c}\text { Quantity } \\
\text { Purchased }\end{array}$ & Purchases & $\begin{array}{c}\text { Quantity } \\
\text { Purchased }\end{array}$ & Purchases & $\begin{array}{l}\text { Quantity } \\
\text { Purchased }\end{array}$ \\
\hline & Number & Quarts & Number & Quarts & Number & Quarts \\
\hline or 60 ) & 575 & 4,754 & 120 & 1,059 & 267 & 2,340 \\
\hline $\begin{array}{l}2,(1958-59) \\
2,(1959-60)\end{array}$ & & & $\begin{array}{l}294 \\
123\end{array}$ & $\begin{array}{l}2,186 \\
1,073\end{array}$ & 125 & \\
\hline $\overrightarrow{3},(1958-59-60)$ & 967 & 6,595 & 940 & 6,494 & 939 & 6,299 \\
\hline TOTAL & 1,858 & 13,782 & 1,477 & 10,812 & 1,331 & 9,711 \\
\hline
\end{tabular}

The records of purchases by the one-year customers are summarized in Table 1. However, they were not analyzed since they were not the same customers from one year to the next. Thus, no valid basis for comparison existed.

The records of purchases by the two-year customers were analyzed, but not in great detail. Data from sales made to the two-year customers, who received home delivery during 1958 and 1959, indicated a reduction of 247 quart equivalents of fluid milk purchased from 1958 to 1959 (Table 1). This was a reduction of 10.2 per cent. However, the other group of the two-year customers who began receiving home delivery in 1959 and continued throughout 1960, purchased 1,073 quart equivalents of fluid milk during the selected week within the twice-weekly delivery year. This more than offset the reduction in the quantity of fluid milk purchased by the first group of two-year customers during 1959. Thus, neither group of two-year customers provided relevant data for the analysis of consumer purchasing patterns before, during, and after the twice-weekly delivery experience.

Since the one-year and two-year customers did not provide a relevant basis for analysis, the detailed analysis of consumer purchasing patterns was conducted from data compiled from purchases by the 735 three-year customers in the study. These customers purchased 48, 60, and 65 per cent of the fluid milk delivered retail by Johnson's Dairy during 1958, 1959, and 1960, respectively. Each individual product purchased by one of these customers was classitied as a separate purchase.

The analysis was divided into three phases. First, consumer purchases of home-delivered fluid milk were analyzed. Second, analysis of consumer purchases of additional home-delivered products was made, and finally, consumer purchases of all home-delivered products were analyzed. 


\section{Fluid Milk Sales}

Fluid milk, as a proportion of total products purchased on home delivery routes, by the three-year customers, ranged downward from 97.2 per cent in 1958 to 96.5 per cent in 1960 (Table 2). Thus, the change in fluid milk purchases will greatly affect the overall change in purchases of total products on home-delivery routes by these customers.

The twice-weekly delivery experience apparently resulted in some customers changing their preference for, and acceptance of, less frequent delivery. During 1958, only 5.3 per cent of the number of fluid milk purchases (2.4 per cent of milk) made by the three-year home delivery customers were delivered on a twice-weekly or less-frequent basis. During 1960 , following the twice-weekly delivery experience, this same group of customers chose to receive almost 21 per cent of its purchases (12.6 per cent of milk) on a twice-weekly or less-frequent delivery basis (Tables 3 and 4 ).

Table 2. Products Delivered by Johnson's Dairy to Customers Receiving Retail Delivery During Selected Week of October, Three Consecutive Years, Ashland, Kentucky, 1958, 1959, and 1960

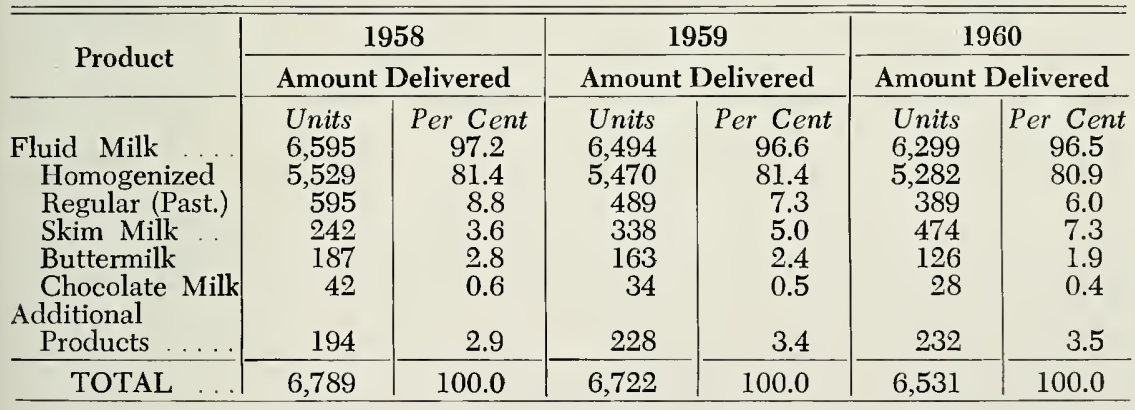

Table 3. Percentage of Total Milk Purchases* Made With Various Frequencies of Milk Delivery During Three Consecutive Years, from Johnson's Dairy, Ashland, Kentucky, 1958, 1959, ANd 1960

\begin{tabular}{c|r|c|r}
\hline \hline \multirow{2}{*}{$\begin{array}{c}\text { Deliveries } \\
\text { Per Week }\end{array}$} & \multicolumn{3}{|c}{ Year } \\
\cline { 2 - 4 } & 1958 & 1959 & 1960 \\
\cline { 2 - 4 } 1 & 1.6 & Percentage of Milk Purchases \\
2 & 3.7 & 1.9 & 4.1 \\
3 & 94.7 & 90.4 & 16.7 \\
4 & $\ldots$ & 7.6 & 79.2 \\
\hline TOTAL & 100.0 & 0.1 & 100.0 \\
\hline
\end{tabular}

* Made by the same 735 customers in each of the years shown. 
Table 4. Percentage of Quantities of Milk* Delivered, by Frequency of Delivery, to Three-Year Customers, Johnson's Dairy, Ashland, KeNTUCKY, 1958, 1959, AND 1960

\begin{tabular}{c|r|r|r}
\hline Deliveries & \multicolumn{3}{|c}{ Year } \\
Per Week & $\mathbf{1 9 5 8}$ & $\mathbf{1 9 5 9}$ & $\mathbf{1 9 6 0}$ \\
\cline { 2 - 4 } 1 & 0.5 & 0.7 & 1.6 \\
2 & 1.9 & 86.7 & 11.0 \\
3 & 97.6 & 12.2 & 87.4 \\
4 & $\ldots$ & 0.4 & $\ldots$ \\
\hline TOTAL & 100.0 & 100.0 & 100.0 \\
\hline
\end{tabular}
late Milk.

"Includes: Homogenized, Regular (Pasteurized), Skim, Buttermilk, and Choco-

The three-year customers purchased 6,595 quart equivalents of fluid milk on home delivery during the week surveyed in 1958, while in 1959 their purchases decreased to 6,494 quart equivalents, and in 1960 the quantity that they purchased decreased further to 6,299 quart equivalents (Table 5). Thus, these same customers, during the twice-weekly delivery experience in 1959 , purchased 1.5 per cent less fluid milk than they had purchased during the selected week the previous year. However, in 1960, when these customers were again offered three deliveries per week, the quantity of fluid milk which they purchased was 3 per cent less than the quantity which they had purchased during the twiceweekly delivery experience (Table 6).

These percentage declines, however, are similar to the percentage decreases in national per capita milk consumption which took place during the corresponding time periods. National per capita consumption of fluid milk decreased by 1.7 per cent from 1958 to 1959 . From 1959 to 1960, the decrease was 1.5 per cent. ${ }^{4}$

The analysis of fluid milk purchases, by the quantity of each type of product, indicated that the quantities of homogenized milk, regular milk, buttermilk, and chocolate milk decreased from 1958 to 1959. These decreases ranged from 1.1 per cent for homogenized milk to 19 per cent for chocolate milk. During the same time period, the quantity of skim milk, purchased on home delivery routes, increased by 39.7 per cent. The same trend continued from 1959 to 1960, with only skim milk showing an increase. Skim milk, however, increased from 338 to 474 quarts or 40.2 per cent (Table 6). These data indicate that consumers' tastes and preferences are changing toward an increased usage of low-fat fluid milk although these products still constitute a relatively small portion of total milk sales.

${ }^{4}$ U.S.D.A., Dairy Statistics Through 1960, Statistical Bull. No. 303-Supplement for 1962, Economic Research Service, Nov,, 1963, p. 139. 


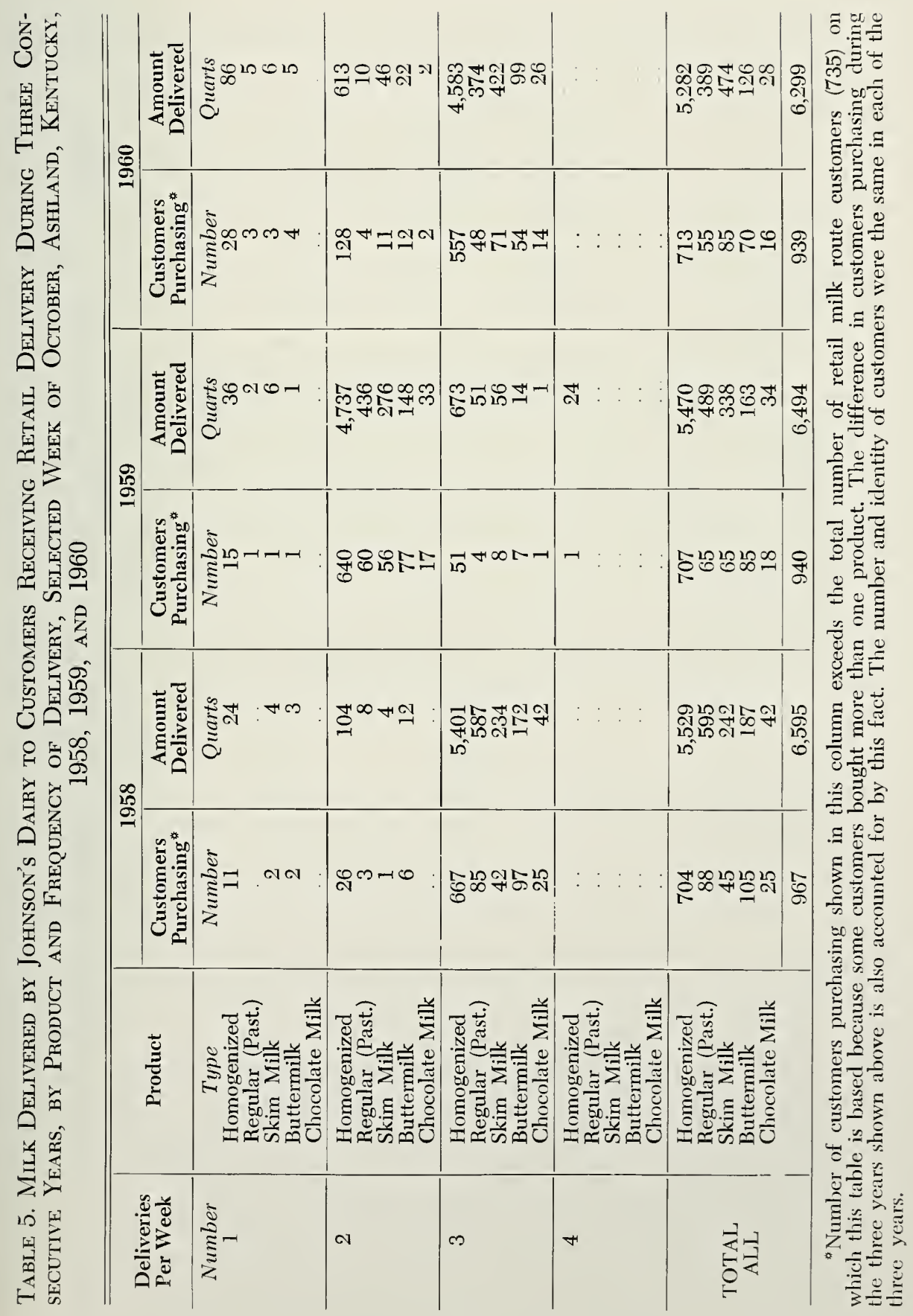


Table 6. Change in Quantity of Fluid Milk Sold to Three-Year Customers by Johnson's Dairy, Ashland, Kentucky, During Selected WEeK OF OCTOBER, 1958, 1959, AND 1960

\begin{tabular}{|c|c|c|c|c|c|}
\hline \multirow[b]{2}{*}{ Product } & 1958 & 1959 & \multirow{2}{*}{$\begin{array}{c}\text { Change } \\
1958 \text { to } 1959\end{array}$} & 1960 & \multirow{2}{*}{$\begin{array}{c}\text { Change } \\
1959 \text { to } 1960\end{array}$} \\
\hline & $\begin{array}{c}\text { Quantity } \\
\text { Purchased }\end{array}$ & $\begin{array}{c}\text { Quantity } \\
\text { Purchased }\end{array}$ & & $\begin{array}{c}\text { Quantity } \\
\text { Purchased }\end{array}$ & \\
\hline $\begin{array}{l}\text { Homogenized } \\
\text { Regular (Past.) } \\
\text { Skim Milk } \\
\text { Chocolate Milk } \\
\text { Buttermilk }\end{array}$ & $\begin{array}{c}\text { Quarts } \\
5,529 \\
595 \\
242 \\
42 \\
187 \\
\end{array}$ & $\begin{array}{c}\text { Quarts } \\
5,470 \\
489 \\
338 \\
34 \\
163 \\
\end{array}$ & $\begin{array}{c}\text { Per Cent } \\
-1.1 \\
-17.8 \\
+39.7 \\
-19.0 \\
-12.8\end{array}$ & $\begin{array}{c}\text { Quarts } \\
5,282 \\
389 \\
474 \\
28 \\
126\end{array}$ & $\begin{array}{c}\text { Per Cent } \\
-3.4 \\
-20.4 \\
+40.2 \\
-17.6 \\
-22.7 \\
\end{array}$ \\
\hline $\begin{array}{c}\text { TOTAL OR } \\
\text { AVERAGE }\end{array}$ & 6,595 & 6,494 & -1.5 & 6,299 & -3.0 \\
\hline
\end{tabular}

The analysis of the various types of fluid milk purchased, as a percentage of the total fluid milk purchased, reaffirmed the trend toward increased consumption of skim milk. This was the only type of fluid milk to show an increase during all three years, increasing from 3.7 per cent of the total in 1958 to 8.5 per cent in 1960 . Homogenized milk accounted for over 83 per cent of the total during each of the three years examined ( Table 7).

Table 7. Proportion of Milk Delivered, by Product, to Three-Year Customers, Johnson's Dairy, Ashland, Kentucky, 1958, 1959, AND 1960

\begin{tabular}{|c|c|c|c|}
\hline Product & 1958 & 1959 & 1960 \\
\hline $\begin{array}{l}\text { Homogenized } \\
\text { Regular (Past.) } \\
\text { Skim Milk .... } \\
\text { Buttermilk } \\
\text { Chocolate Milk }\end{array}$ & $\begin{array}{c}\text { Per Cent } \\
83.9 \\
9.0 \\
3.7 \\
2.8 \\
0.6\end{array}$ & $\begin{array}{c}\text { Per Cent } \\
84.3 \\
7.5 \\
5.2 \\
2.5 \\
0.5\end{array}$ & $\begin{array}{c}\text { Per Cent } \\
83.9 \\
6.2 \\
7.5 \\
2.0 \\
0.4\end{array}$ \\
\hline TOTAL & 100.0 & 100.0 & 100.0 \\
\hline
\end{tabular}

Since homogenized milk accounted for over 83 per cent of the fluid milk delivered, the differences were tested to determine if the variance from year to year was significant. Analysis of variance indicated that the decrease in the quantity of homogenized milk delivered, throughout the three years studied, was not significant."

Use of Duncan's New Multiple Range Test indicated that there was no significant difference between the average quantity of homogenized milk delivered during the twice-weekly delivery year (1959) and the average quantity delivered during either of the years (1958 and 1960) in which three deliveries per week were offered to customers.

As indicated in Table 6, skim milk was the only fluid milk product sales of which increased during each of the three years examined. Therefore, it seemed advisable to test the significance of the increase from year

5The tabular $F$ value (10.65) exceeded the calculated $F$ value, (.00082). 
to year. Analysis of variance indicated that the increase in purchases of skim milk during this period was not significant." Duncan's New Multiple Range Test showed that there was no significant difference between the average quantity of skim milk delivered during the twice-weekly delivery year and the average quantity delivered during either of the years in which three deliveries per week were offered.

The above tests have shown that there was no significant difference in the quantities of homogenized milk and the quantities of skim milk delivered from year to year. As indicated in Table 7, these two products accounted for 87 per cent to 91 per cent of the total fluid milk which was delivered to the three-year customers, over the three-year period examined. It seemed advisable to examine the decrease in the total quantity of fluid milk delivered as it was shown in Table 6 . Analysis of variance indicated that the decrease in the quantity of fluid milk purchased during the period of the study was not significant. ${ }^{7}$ Duncan's New Multiple Range Test indicated that there was no significant difference in the average quantity of fluid milk delivered during the twice-weekly delivery year and the average quantity delivered during either the preceding year or the following year, when three deliveries per week were offered.

Even though the quantity of milk purchased by the three-year customers did not vary significantly from year to year, it seemed desirable to examine the effect which price changes and total revenue changes had on the twice-weekly delivery operation.

\section{Price Influence}

The average price per unit of fluid milk, delivered to the three-year customers, increased during each time period examined. Average price per unit for different types of fluid milk also covered a wide range within each year, respectively. In 1958, the average price per quart equivalent ranged from a low of 21.2 cents for skim milk, to a high of 28.5 cents for chocolate milk. In 1959, the average price ranged from 22.2 cents per quart equivalent for skim milk to 29.2 for chocolate milk, and in 1960 skim milk was priced at 24.5 cents per quart equivalent while the price of chocolate milk averaged 31.4 cents per quart equivalent (Table 8 ).

During the period of the twice-weekly delivery experience (1959), the average price per quart equivalent for all fluid milk delivered was 26.2 cents compared with an average price of 25.6 cents per quart equivalent during 1958, when delivery was offered three times a week. This was an increase of 2.3 per cent in the average price of fluid milk delivered. Price increases for the various types of fluid milk during this period ranged from 2.3 per cent for chocolate and homogenized milk, to 4.7 per cent for skim milk (Table 9 ).

${ }^{6}$ The tabular $\mathrm{F}$ value (10.65) exceeded the calculated $\mathrm{F}$ value, (.1797).

The tabular $\mathrm{F}$ value $(6.06)$ exceeded the calculated $\mathrm{F}$ value, $(.4855)$. 
Table 8. Average Prices and Rflative Importance of Fluid Mitk Sold to Three-Year Customers by Johnson's Dairy, Ashland, Kentucky, During Selected Week of October, 1958, 1959, and 1960

\begin{tabular}{|c|c|c|c|c|c|c|}
\hline \multirow[b]{2}{*}{ Product } & \multicolumn{2}{|c|}{1958} & \multicolumn{2}{|c|}{1959} & \multicolumn{2}{|c|}{1960} \\
\hline & Quantity & $\begin{array}{l}\text { Avg. Price } \\
\text { Per Quart }\end{array}$ & Quantity & $\begin{array}{l}\text { Avg. Price } \\
\text { Per Quart }\end{array}$ & Quantity & $\begin{array}{l}\text { Avg. Price } \\
\text { Per Quart }\end{array}$ \\
\hline $\begin{array}{l}\text { Homogenized } \\
\text { Regular (Past.) } \\
\text { Skim Milk } \\
\text { Chocolate Milk } \\
\text { Buttermilk }\end{array}$ & $\begin{array}{c}\text { Per Cent } \\
83.9 \\
9.0 \\
3.7 \\
0.6 \\
2.8\end{array}$ & $\begin{array}{c}\text { Cents } \\
25.9 \\
25.0 \\
21.2 \\
28.5 \\
24.1 \\
\end{array}$ & $\begin{array}{c}\text { Per Cent } \\
84.3 \\
7.5 \\
5.2 \\
0.5 \\
2.5\end{array}$ & $\begin{array}{c}\text { Cents } \\
26.5 \\
25.9 \\
22.2 \\
29.2 \\
25.3\end{array}$ & $\begin{array}{c}\text { Per Cent } \\
83.9 \\
6.2 \\
7.5 \\
0.4 \\
2.0\end{array}$ & $\begin{array}{c}\text { Cents } \\
27.3 \\
27.4 \\
24.5 \\
31.4 \\
26.2 \\
\end{array}$ \\
\hline $\begin{array}{c}\text { TOTAL OR } \\
\text { AVERAGE } \\
\end{array}$ & 100.0 & 25.6 & 100.0 & 26.2 & 100.0 & 27.1 \\
\hline
\end{tabular}

Table 9. Change in Average Prices of Fluid Milk Sold to Three-Year Customers by Johnson's Dairy, Ashland, Kentucky, During Selected WeEk of OCtOBER, 1958, 1959, ANd 1960

\begin{tabular}{|c|c|c|c|c|c|}
\hline Product & $\begin{array}{c}1958 \\
\text { Avg. Price } \\
\text { Per Quart }\end{array}$ & $\begin{array}{c}1959 \\
\text { Avg. Price } \\
\text { Per Quart }\end{array}$ & $\begin{array}{c}\text { Increase } \\
1958 \text { to } 1959\end{array}$ & $\begin{array}{c}1960 \\
\text { Avg. Price } \\
\text { Per Quart }\end{array}$ & $\begin{array}{c}\text { Increase } \\
1959 \text { to } 1960\end{array}$ \\
\hline $\begin{array}{l}\text { Homogenized } \\
\text { Regular (Past.) } \\
\text { Skim Milk } \\
\text { Chocolate Milk } \\
\text { Buttermilk .... }\end{array}$ & $\begin{array}{l}\text { Cents } \\
25.9 \\
25.0 \\
21.2 \\
28.5 \\
24.1 \\
\end{array}$ & $\begin{array}{l}\text { Cents } \\
26.5 \\
25.9 \\
22.2 \\
29.2 \\
25.3\end{array}$ & $\begin{array}{c}\text { Per Cent } \\
2.3 \\
3.6 \\
4.7 \\
2.3 \\
4.7 \\
\end{array}$ & $\begin{array}{l}\text { Cents } \\
27.3 \\
27.4 \\
24.5 \\
31.4 \\
26.2 \\
\end{array}$ & $\begin{array}{c}\text { Per Cent } \\
2.9 \\
6.0 \\
10.2 \\
7.7 \\
3.6 \\
\end{array}$ \\
\hline $\begin{array}{c}\text { AVERAGE OR } \\
\text { TOTAL }\end{array}$ & 25.6 & 26.2 & 2.3 & 27.1 & 3.2 \\
\hline
\end{tabular}

However, in 1959, home-delivered milk in Ashland, Kentucky, cost two cents more than store-purchased milk, when purchased in quart containers. The Ashland consumer paid three cents per quart equivalent above the store price for milk purchased in one-half gallon containers. When the consumer purchased milk in the gallon glass container, the cost per quart equivalent was 2.75 cents above the store price. These price differentials apparently did not have a significant effect on homedelivered purchases, since two-thirds of the consumers interviewed in Ashland during the summer of 1961 were willing to pay at least two cents per quart for the convenience of home delivery. ${ }^{8}$

During the year following the twice-weekly delivery experience, the average price per quart equivalent for all home-delivered fluid milk was 27.1 cents or an increase of 3.4 per cent above the 1959 average price. Price increases for individual types of fluid milk during this period ranged from a 3 per cent increase in homogenized milk prices to an increase of 11 per cent in the average price of skim milk (Table 9). Sta-

sAdrian L. Haught, Consumers' Milk Buying Habits, Reactions to Reduced Deliveries. Unpublished Master's Thesis, West Virginia Univ., Morgantown, W. Va., July, 1963. 
tistical analyses indicated that these price differences were not significant.

From 1958 to 1959 , the volume of skim milk purchased by the same customers increased by about 40 per cent (Table 6 ). During the same time period, the average price per quart of skim milk increased by 4.7 per cent (Table 9). Corresponding figures for the period from 1959 to 1960 show an increase of more than 40 per cent in the quantity of skim milk purchased, and an increase in average price of 10.2 per cent. Even though the increase in the average price of skim milk was greater than the increase in the average price of any other fluid milk product, skim milk was the only product to show an increase in the volume purchased during each of the years studied.

Skim milk sales are becoming somewhat more important to the overall operation of the retail milk distributor. Skim milk sales which accounted for only 3 per cent of the total revenue from fluid milk sales to the three-year customers in 1958, accounted for 4.4 per cent of the total in $1959,6.8$ per cent in 1960 , and were second only to the total revenue from sales of homogenized milk (Table 10 ).

If it were assumed that factors other than price and quantity remained constant, certain conclusions might be drawn regarding the price elasticity of the home-delivered fluid milk during the years examined. First, consider the period from 1958 to 1959, when the change was made to twice-weekly delivery. The percentage change in quantity $(-1.5$ per cent from Table 6 ), divided by the percentage change in price ( 2.3 per cent from Table 9 ), would result in a price elasticity of -0.7 per cent. This result is within the range determined by previous studies. The corresponding data for the period from 1959 to 1960, when the company reverted from twice-weekly back to three-times-a-week delivery, were -3.0 divided by 3.2 , which resulted in a price elasticity of -0.9 . This, again, seems reasonable when it is acknowledged that the situation was not a static one.

Table 10. Total Revenue from Fluid Milk Sales to Three-Year Customers by Johnson's Dairy, Ashland, Kentucky, During Selected WeEK OF OCTOBER, 1958, 1959, AND 1960

\begin{tabular}{r|r|r|r|r|r|r}
\hline \multirow{2}{*}{ Product } & \multicolumn{2}{|c|}{1958} & \multicolumn{2}{c|}{1959} & \multicolumn{2}{c}{1960} \\
\cline { 2 - 6 } & \multicolumn{2}{|c|}{ Amount } & \multicolumn{2}{c}{ Amount } & \multicolumn{2}{c}{ Amount } \\
\cline { 2 - 7 } & Dollars & Per Cent & Dollars & Per Cent & Dollars & Per Cent \\
Homogenized & $1,432.03$ & 84.8 & $1,449.58$ & 85.2 & $1,440.11$ & 84.5 \\
Regular (Past.) & 148.49 & 8.8 & 126.46 & 7.4 & 106.64 & 6.3 \\
Skim Milk . & 51.38 & 3.0 & 75.14 & 4.4 & 116.13 & 6.8 \\
Chocolate Milk & 11.98 & 0.7 & 9.92 & 0.6 & 8.80 & 0.5 \\
Buttermilk ... & 45.15 & 2.7 & 41.19 & 2.4 & 32.98 & 1.9 \\
\hline TOTAL ... & $1,689.03$ & 100.0 & $1,702.29$ & 100.0 & $1,704.66$ & 100.0 \\
\hline
\end{tabular}


With this inelastic demand, and an increase in price, one would have expected an increase in total revenue. Total revenue did increase.

\section{Total Revenue from Sales}

Total revenue from home-delivered fluid milk sales to the three-year customers during the selected week in 1958 was $\$ 1,689.03$. Total revenue for the corresponding week during the twice-weekly delivery year was $\$ 1,702.29$, or an increase of 0.8 per cent in total revenue from fluid milk sales. Total revenue, by products, in 1958 , ranged from $\$ 11.98$ or 0.7 per cent of the total for chocolate milk, to $\$ 1,432.03$ or 84.8 per cent for homogenized milk. During twice-weekly delivery in 1959, the corresponding totals were $\$ 9.92$ for chocolate milk ( 0.6 per cent) and $\$ 1,449.58$ for homogenized milk ( 85.2 per cent), (Table 10 ).

During 1960, when three deliveries per week were again offered, and the average price increased by 3.2 per cent, total revenue from fluid milk sales during the selected week was $\$ 1,704.66$, or an increase of only 0.14 per cent over the total for the selected week during the twice-weekly delivery years.

Previous analysis herein had shown that there was no significant difference in the quantity of fluid milk delivered during the twice-weekly delivery year and the quantity delivered during either the year preceding or the year following, when three deliveries per week were offered. Also, the average price per quart equivalent did not vary significantly during any of the three years. Nevertheless, it still seemed advisable to statistically test the difference in total revenue during each of the three years. The differences were found to be non-significant.

Thus, it was concluded that there was no significant ${ }^{9}$ difference in the quantity of fluid milk purchased by the three-year customers, during 1959, the year of the twice-weekly delivery, and the quantity purchased by the same customers during 1958 and 1960, the years in which three deliveries per week were offered.

\section{Analysis of Additional Product Sales}

Johnson's Dairy and other milk distributors deliver products other than fluid milk on their home delivery routes. Products other than fluid milk, which were delivered in significant quantities, during all three years included: ice cream, cottage cheese, butter, orange drink, and frozerta (Table 11). In 1959, margarine and half and half (a coffee creamer) became available on home delivery routes. The availability of these products coincided with the year of the twice-weekly delivery experience and continued to the end of the period studied.

${ }^{9}$ The difference was not significant at the .05 level of probability. 


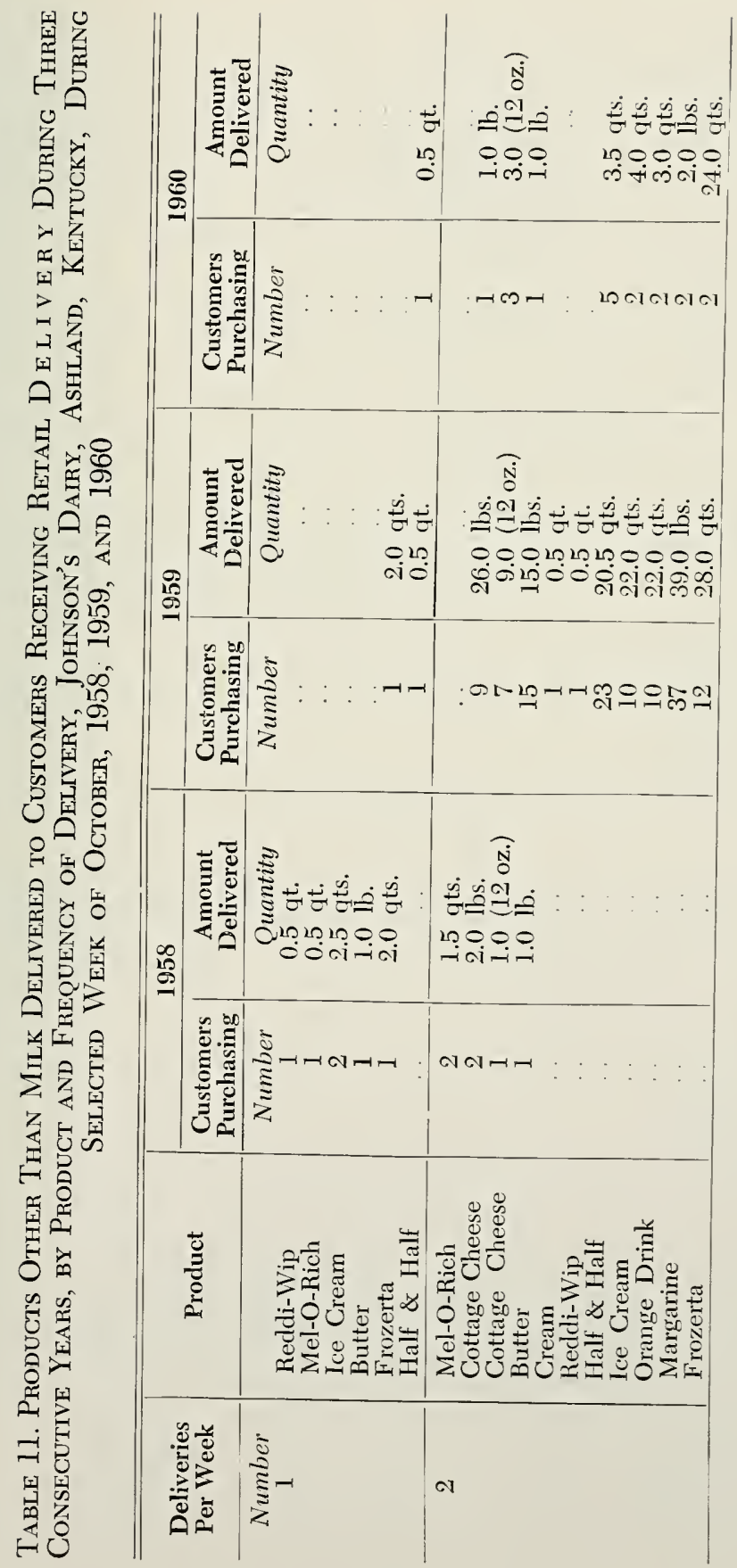




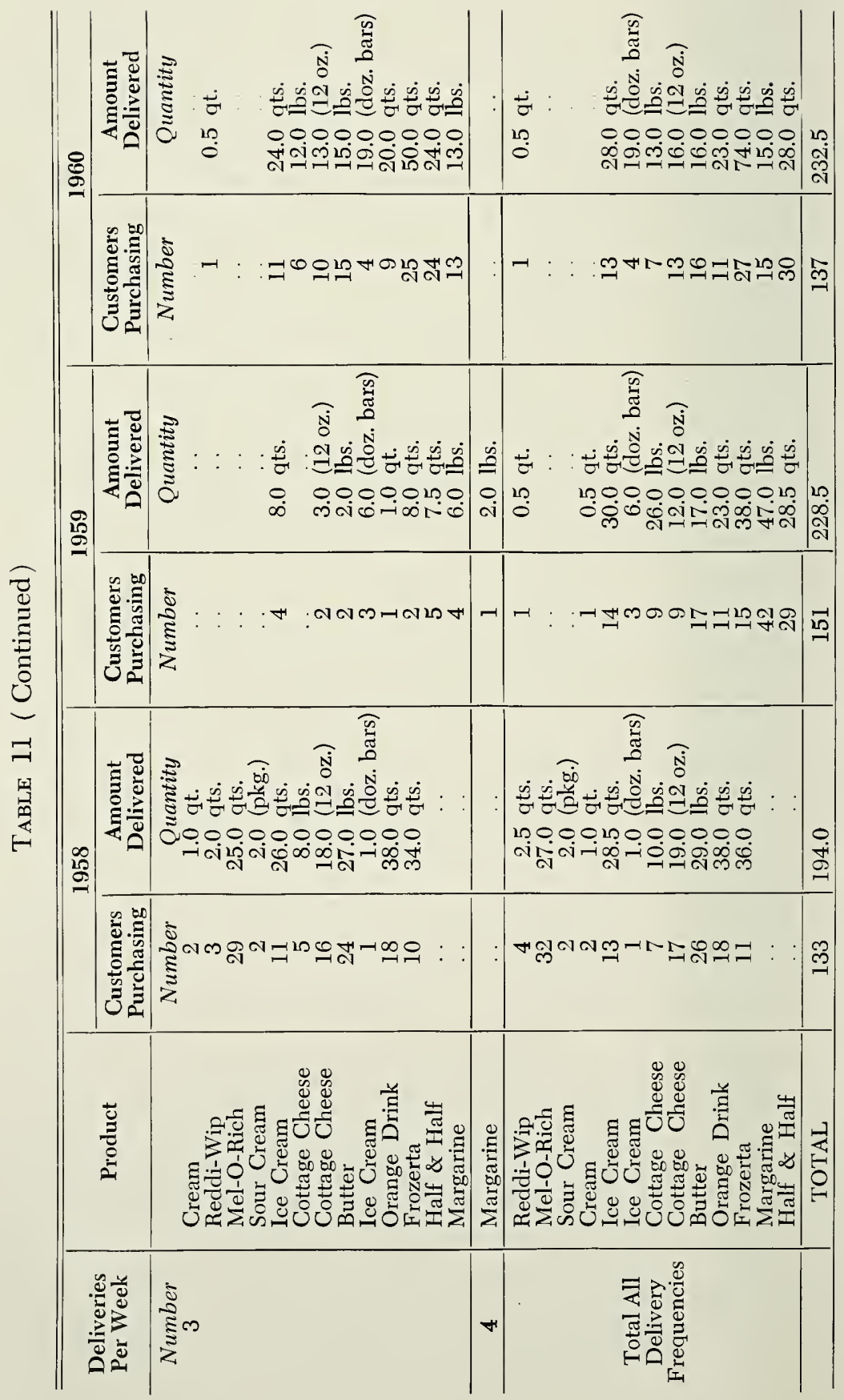


Products other than fluid milk accounted for 2.9 per cent of the totaI quantity of all products delivered to the three-year customers in 1958. During the twice-weekly delivery experience in 1959, additional products accounted for 3.4 per cent of the total, while in 1960, these products accounted for 3.6 per cent of the total (Table 2). These data indicate that additional products were becoming somewhat more important in the overall delivery operation of the milk distributor, however, at that time they comprised only a small proportion of his total sales.

Following the twice-iveekly delivery year, over 18 per cent of all the quantities of additional products delivered ( 14 per cent of purchases), were delivered on a twice-weekly or less-frequent delivery basis. Prior to twice-weekly delivery, less than 7 per cent of the quantities of additional products ( 9 per cent of purchases) had been delivered on a frequency of less than three times a week (Tables 12 and 13). These data indicate a definite change in consumer purchasing patterns for additional products, following the twice-weekly delivery experience.

The three-year customers purchased a total of 194 units of additional products during the week selected in 1958. In 1959, during the twice-weekly experience, these same customers purchased 228.5 units of

Table 12. Proportion of Purchases of Additional Products on Retail Milk Routes, by Frequency of Delivery, from Johnson's Dairy, AshLAND, KentuCKy, 1958, 1959, AND 1960

\begin{tabular}{c|c|c|c}
\hline \hline Deliveries Per Week & 1958 & 1959 & 1960 \\
\cline { 2 - 4 } Number & Per Cent & Per Cent & Per Cent \\
1 & 4.5 & 1.3 & 0.7 \\
2 & 4.5 & 82.8 & 13.2 \\
3 & 91.0 & 15.2 & 86.1 \\
4 & & 0.7 & $\ldots$ \\
\hline TOTAL & 100.0 & 100.0 & 100.0 \\
\hline
\end{tabular}

Table 13. Quantities and Relative Importance of A d d i t i o n a l Products Purchased by Three-Year Customers, by Frequency of Delivery, from Johnson's Dairy, Ashland, Kentucky, Selected Week OF OCtOBER, 1958, 1959, AND 1960

\begin{tabular}{|c|c|c|c|c|c|c|}
\hline \multirow{2}{*}{$\begin{array}{l}\text { Deliveries } \\
\text { Per Week }\end{array}$} & \multicolumn{2}{|c|}{1958} & \multicolumn{2}{|c|}{1959} & \multicolumn{2}{|c|}{1960} \\
\hline & \multicolumn{2}{|c|}{ Quantity Purchased } & \multicolumn{2}{|c|}{ Quantity Purchased } & \multicolumn{2}{|c|}{ Quantity Purchased } \\
\hline $\begin{array}{c}\text { Number } \\
1 \\
2 \\
3 \\
4\end{array}$ & $\begin{array}{r}\text { Units } \\
6.5 \\
5.5 \\
182.0\end{array}$ & $\begin{array}{c}\text { Per Cent } \\
3.4 \\
2.8 \\
93.8\end{array}$ & $\begin{array}{r}\text { Units } \\
2.5 \\
182.5 \\
41.5^{*} \\
2.0^{*}\end{array}$ & $\begin{array}{c}\text { Per Cent } \\
1.1 \\
79.9 \\
18.1^{\circ} \\
0.9^{\circ}\end{array}$ & $\begin{array}{r}\text { Units } \\
0.5 \\
41.5 \\
190.5\end{array}$ & $\begin{array}{c}\text { Per Cent } \\
0.2 \\
17.8 \\
81.9\end{array}$ \\
\hline TOTAL & 194.0 & 100.0 & 228.5 & 100.0 & 232.5 & 100.0 \\
\hline
\end{tabular}

*A limited number of customers received deliveries from more than one route. 
additional products, or an increase of 17.8 per cent over the amount which they had purchased when three deliveries per week were offered. In 1960 , the amount of additional products purchased was 232.5 units, or an increase of only 1.8 per cent from the amount purchased during 1959 , when only two deliveries per week were offered (Table 14). Thus, when the company reverted back to three deliveries per week in 1960, it did not greatly increase the sale of additional products on home delivery routes.

However, the quantity of additional products purchased during the twice-weekly delivery year was not significantly different from the quantity purchased prior to the adoption of the twice-weekly delivery services. ${ }^{10}$ Even though the quantity of additional products purchased did not vary significantly from year to year, it seemed advisable to examine the changes in price and the change in total revenue which occurred over the three-year period.

Average price per unit of additional products delivered decreased from 45.2 cents per unit in 1958 to 42.9 cents per unit in 1959. This was a decrease of 5.1 per cent in the average price per unit delivered (Table 14). This decrease occurred partially as a result of the addition of margarine and half and half on the market in 1959. These products both had low unit prices relative to the other additional products which were offered on the home delivery routes.

From 1959 to 1960, the average price of additional products delivered, increased by 12.2 per cent to an average of 48.1 cents per unit (Table 14). During the same period, the total quantity of additional products purchased on home delivery increased by 1.8 per cent. There was an apparent increase in the demand for additional products the cause for which was not determined by this study. This increased demand may or may not have been related to the company's reversion to three deliveries per week.

Weekly revenue from the sale of additional products increased from $\$ 87.75$, in 1958 , to $\$ 97.95$ during the twice-weekly delivery year. This was an increase of $\mathbf{1 1 . 6}$ per cent. The increase in demand for additional products on home delivery routes, from 1959 to 1960, was accompanied by a 14.2 per cent increase in total revenue from these products, which increased from $\$ 97.95$ in 1959 to $\$ 111.84$ during the selected week in 1960 (Table 14).

During the twice-weekly delivery experience in 1959, almost 80 per cent of the total revenue from the sale of additional products was from the sale of products purchased on twice-weekly or less-frequent delivery. Following the twice-weekly experience, only 14 per cent of the revenue

${ }^{10}$ The tabular $F$ value (7.57) exceeded the calculated $F$ value, (.5488). 
Table 14. Total Sales, Revenue, and Prices of Additional Products Delivered to Three-Year Customers by Johnson's Dairy, Ashland, Kentucky, During Selected Week of October, 1958, 1959, ANd 1960

\begin{tabular}{|c|c|c|c|c|c|}
\hline $\begin{array}{c}\text { Sales, Revenue, } \\
\text { Prices }\end{array}$ & 1958 & 1959 & $\begin{array}{c}\text { Percentage } \\
\text { Change } \\
1958 \text { to } 1959 \\
\end{array}$ & 1960 & $\begin{array}{c}\text { Percentage } \\
\text { Change } \\
1959 \text { to } 1960\end{array}$ \\
\hline $\begin{array}{l}\text { Total Sales } \\
\text { (Number) } \\
\text { Total Quantity }\end{array}$ & 133.00 & 151.00 & +13.5 & 137.00 & -9.3 \\
\hline $\begin{array}{l}\text { Delivered } \\
\text { (Units) } \\
\text { Total Revenue }\end{array}$ & 194.00 & 228.50 & +17.8 & 232.50 & +1.8 \\
\hline $\begin{array}{l}\text { Received } \\
\text { (Dollars) } \\
\text { Average Price Per }\end{array}$ & 87.75 & 97.95 & +11.6 & 111.84 & +14.2 \\
\hline $\begin{array}{l}\text { Unit Delivered } \\
\text { (Cents) ....... }\end{array}$ & 45.23 & 42.87 & -5.2 & 48.10 & +12.2 \\
\hline
\end{tabular}

was from sales on twice-weekly or less frequent delivery, while prior to the twice-weekly experience, less than 8 per cent of the revenue was from sales of this nature (Table 15). These data indicated a change in consumer purchasing patterns for additional products, and showed that after being exposed to twice-weekly delivery, many consumers chose to continue purchasing additional products on the less-frequent delivery basis.

Table 15. Total Revenue from the Sale of Additional Products, by Frequency of Delivery, to Three-Year Customers, Johnson's Dairy, Ashland, Kentucky, During Selected Week of October, 1958, 1959, AND 1960

\begin{tabular}{|c|c|c|c|c|c|c|}
\hline \multirow{2}{*}{$\begin{array}{l}\text { Deliveries } \\
\text { Per Week }\end{array}$} & \multicolumn{2}{|c|}{1958} & \multicolumn{2}{|c|}{1959} & \multicolumn{2}{|c|}{1960} \\
\hline & \multicolumn{2}{|c|}{ Revenue } & \multicolumn{2}{|c|}{ Revenue } & \multicolumn{2}{|c|}{ Revenue } \\
\hline $\begin{array}{c}\text { Number } \\
1 \\
2 \\
3 \\
4 \\
\end{array}$ & $\begin{array}{c}\text { Dollars } \\
3.67 \\
2.85 \\
81.23\end{array}$ & $\begin{array}{c}\text { Per Cent } \\
4.2 \\
3.2 \\
92.6 \\
\ldots\end{array}$ & $\begin{array}{c}\text { Dollars } \\
0.99 \\
76.41 \\
19.85 \\
0.70\end{array}$ & $\begin{array}{c}\text { Per Cent } \\
1.0 \\
78.0 \\
20.3 \\
0.7\end{array}$ & $\begin{array}{r}\text { Dollars } \\
0.42 \\
15.39 \\
96.03\end{array}$ & $\begin{array}{r}\text { Per Cent } \\
0.4 \\
13.8 \\
85.8\end{array}$ \\
\hline $\begin{array}{l}\text { TOTAL-ALL } \\
\text { DELIVERIES }\end{array}$ & 87.75 & 100.0 & 97.95 & 100.0 & 111.84 & 100.0 \\
\hline
\end{tabular}

\section{Analysis of Combined Product Sales}

After separate analysis, it appeared advisable to combine the data from fluid milk purchases and the data from additional product purchases for collective analysis.

The preceding analysis has shown a decrease in the quantity of fluid milk sold on home delivery routes to the three-year customers during the twice-weekly delivery year, and an increase in the quantity of additional products sold to the same customers. Neither change in quantity was found to be significant at the .65 level of probability. However, since the 
quantity changes were moving in opposite directions, they partially offset each other, leaving less than a 1 per cent decrease in the total quantity of all products purchased by three-year customers. It was concluded that there was no significant difference in the quantity of home-delivered products purchased by the three-year customers during the year of twiceweekly delivery and the preceding or following years when three deliveries per week were offered (Table 16).

Table 16. Total Sales of All Products to Three-Year Customers, Johnson's Dairy, Ashland, Kentucky, During Selected Week of OCTOBER, 1958, 1959, AND 1960

\begin{tabular}{|c|c|c|c|c|c|}
\hline Sales & 1958 & 1959 & $\begin{array}{c}\text { Percentage } \\
\text { Change } \\
1958 \text { to 1959 }\end{array}$ & 1960 & \begin{tabular}{|c} 
Percentage \\
Change \\
1959 to 1960
\end{tabular} \\
\hline $\begin{array}{l}\text { Total Sales } \\
\text { (Number) } \\
\text { Total Quantity }\end{array}$ & $1,100.00$ & $1,091.00$ & -0.8 & $1,076.00$ & -1.4 \\
\hline $\begin{array}{l}\text { Delivered } \\
\quad \text { (Units) ..... } \\
\text { Total Revenue }\end{array}$ & $6,789.00$ & $6,722.50$ & -1.0 & $6,531.50$ & -2.8 \\
\hline $\begin{array}{l}\text { Received } \\
\text { (Dollars) ... } \\
\text { Average Price Per } \\
\text { Unit Delivered } \\
\text { (Cents) ....... }\end{array}$ & $1,776.78$ & $1,800.24$ & +1.3 & $1,816.50$ & +0.9 \\
\hline
\end{tabular}

\section{Analysis of Consumer Attitudes and Opinions}

This phase of the study dealt with the attitudes and opinions of retail milk route customers concerning less frequent delivery of milk than that which they were currently receiving. The existing frequency of delivery among the households studied in Ashland, Kentucky, and Wheeling, West Virginia, is indicated in Table 17. Approximately three-fourths of the customers received three deliveries per week and 95 per cent received three deliveries or less per week.

\section{Additional Deliveries}

Customers interviewed were questioned about their desires for additional deliveries. Additional deliveries of milk were not desired by the retail route customers (Table 18). As might have been expected, none of the customers then receiving one or two deliveries per week wanted additional deliveries. Only 29 of 697 customers would like to have deliveries made as often as 6 or 7 times per week. There was little difference in customer preferences on desired frequency of delivery between the customers in Ashland and Wheeling. 


\section{Consumers' Attitudes}

A summary of customers' attitudes toward more frequent delivery of milk than they were currently receiving is given in Table 19. Ninety-three per cent did not want additional deliveries and the principal reason given by the few who did desire additional deliveries was to get fresher milk.

Table 17. Number of Milk Deliveries Each Week, Ashland and WHEELING

\begin{tabular}{c|c|c|c|c|c|c}
\hline \hline \multirow{2}{*}{ Deliveries } & \multicolumn{2}{|c|}{$\begin{array}{c}\text { Ashland } \\
\text { Households }\end{array}$} & \multicolumn{2}{c|}{$\begin{array}{c}\text { Wheeling } \\
\text { Households }\end{array}$} & \multicolumn{2}{c}{$\begin{array}{c}\text { Total } \\
\text { Households }\end{array}$} \\
\cline { 2 - 3 } Number & Number & Per Cent & Number & Per Cent & Number & Per Cent \\
1 & 19 & 6 & 26 & 7 & 45 & 6 \\
2 & 42 & 14 & 62 & 16 & 103 & 15 \\
3 & 222 & 75 & 293 & 73 & 516 & 74 \\
4 & 1 & 4 & 6 & 1 & 7 & 1 \\
5 & 11 & 4 & 3 & $*$ & 14 & 2 \\
6 & 3 & 1 & 9 & 3 & 12 & 2 \\
\hline TOTAL & 298 & 100 & 399 & 100 & $697^{*}$ & 100 \\
\hline
\end{tabular}

${ }^{*}$ Less than .5 per cent.

* Total number of households reporting receiving home delivery.

Table 18. Adjitional Weekly Deliveries of Milk Desired

\begin{tabular}{|c|c|c|c|c|c|c|}
\hline $\begin{array}{c}\text { Present } \\
\text { Deliveries } \\
\text { Per Week }\end{array}$ & \multicolumn{6}{|c|}{ Number of Additional Deliveries Desired } \\
\hline Number & 0 & 1 & 2 & 3 & 4 & $\begin{array}{c}\text { Total } \\
\text { Households }\end{array}$ \\
\hline $\begin{array}{l}1 \\
2 \\
3 \\
4 \\
5 \\
6 \\
\end{array}$ & $\begin{array}{r}45 \\
103 \\
471 \\
7 \\
12 \\
12\end{array}$ & 13 & $\begin{array}{l}3 \\
2\end{array}$ & $\begin{array}{c}q u e \\
\ldots \\
i 1 \\
\ldots \\
\ldots\end{array}$ & $\begin{array}{l}\ldots \\
18 \\
\ldots \\
\ldots\end{array}$ & $\begin{array}{c}\text { Number } \\
45 \\
103 \\
516 \\
9 \\
12 \\
12 \\
\end{array}$ \\
\hline TOTAL & 650 & 13 & 5 & 11 & 18 & 697 \\
\hline
\end{tabular}

Table 19. Retall Customers' Attitudes Toward More Frequent Mrlk DELIVERY

\begin{tabular}{|c|c|c|}
\hline Reply Given & \multicolumn{2}{|c|}{ Households } \\
\hline $\begin{array}{l}\text { Did not want more frequent delivery } \ldots \ldots \\
\text { To get fresher milk } \\
\text { Need more on weekends } \\
\text { Don't want too much (milk) at one time } \\
\text { Need a lot of milk } \\
\text { So I wouldn't run out } \\
\text { Less storage problem } \\
\text { Would not need such a large container } \ldots \\
\text { To keep from running out of milk and to } \\
\text { allow more room in refrigerator } \ldots \ldots\end{array}$ & $\begin{array}{c}\text { Number } \\
650 \\
25 \\
6 \\
5 \\
4 \\
3 \\
2 \\
1 \\
1\end{array}$ & $\begin{array}{c}\text { Per Cent } \\
93.3 \\
3.6 \\
0.9 \\
0.7 \\
0.6 \\
0.4 \\
0.3 \\
0.1 \\
\\
0.1\end{array}$ \\
\hline TOTAL $\ldots \ldots \ldots \ldots \ldots \ldots \ldots$ & 697 & 100.0 \\
\hline
\end{tabular}




\section{Payment for Home Delivery}

When milk is delivered to homes there is usually a higher price to cover the cost of delivery. Each respondent was asked, "How many cents per quart above the store price would you pay to have milk delivered to your home?" Table 20 gives the results of this query. Twenty-nine per cent would pay one cent or less per quart for home delivery. Thirty-one per cent would pay two cents. Twenty-one per cent would pay three cents. Only 19 per cent would pay over three cents per quart for home delivery.

There was evidence that Ashland delivery customers were willing to pay more for home delivery than were Wheeling respondents. The data in Table 20 were tested to determine whether a difference existed in the willingness of the respondents in the two cities to pay additional amounts for home delivery. The difference was statistically significant. ${ }^{11}$

The difference might be due partially to the fact that Ashland respondents tended to earn higher weekly incomes than did Wheeling families and thus would be willing to pay more for home delivery.

Table 20. Amount That Delivery Customers Said They Were Willing to Pay Per Quart for Home Milk Delivery*

\begin{tabular}{|c|c|c|c|c|c|c|}
\hline \multirow{2}{*}{$\begin{array}{l}\text { A Payment } \\
\text { For Home } \\
\text { Delivery }\end{array}$} & \multicolumn{2}{|c|}{ Ashland } & \multicolumn{2}{|c|}{ Wheeling } & \multicolumn{2}{|c|}{ Total } \\
\hline & Number & Per Cent & Number & Per Cent & Number & Per Cent \\
\hline $\begin{array}{l}0 \text { to } 1 \text { cent } \\
2 \text { cents } \ldots \\
3 \text { cents } \ldots \\
4 \text { cents } \ldots \\
5 \text { cents . . . } \\
6 \text { cents . . . } \\
7 \text { cents . . . } \\
8 \text { or more } \\
\text { No answer }\end{array}$ & $\begin{array}{r}64 \\
69 \\
78 \\
30 \\
16 \\
1\end{array}$ & $\begin{array}{r}22 \\
23 \\
27 \\
10 \\
5 \\
\cdots \\
1 \\
12\end{array}$ & $\begin{array}{r}138 \\
142 \\
70 \\
7 \\
13\end{array}$ & $\begin{array}{r}34 \\
36 \\
18 \\
2 \\
3 \\
\ldots \\
\ldots\end{array}$ & $\begin{array}{r}202 \\
211 \\
148 \\
37 \\
29 \\
1 \\
.4 \\
4 \\
65\end{array}$ & $\begin{array}{r}29 \\
31 \\
21 \\
5 \\
4 \\
\\
. \\
1 \\
9 \\
\end{array}$ \\
\hline TOTAL & 298 & 100 & 399 & 100 & 697 & 100 \\
\hline
\end{tabular}

"Includes only respondents who were receiving home delivery.

* Less than 0.5 per cent.

\section{Twice-Weekly Milk Delivery Not Acceptable}

In general, twice-a-week delivery would not be accepted among home delivery receivers in either of the cities (Ashland, Kentucky, or Wheeling, West Virginia) which were involved in this study. Of the 697 households that were getting home delivery, there were 400 that were opposed to twice-a-week milk delivery.

Representatives of 146 households out of 697 , or 21 per cent, that received home delivery indicated that they would be willing to accept

${ }^{11}$ The calculated value was 110.30 . The tabular value at the 0.05 level is 14.07 with 7 degrees of freedom. 
twice-a-week delivery. These families were receiving 19 per cent of the home-delivered milk. Almost an equal number (148) indicated that they were then taking delivery less than three times weekly while three respondents expressed no opinion.

The 148 householders who indicated that they were already getting home delivery only one or two times each week obviously were not opposed to twice-a-week delivery because they could have had more frequent delivery if they had chosen to have it. These households also represented 21 per cent of those that were getting home delivered milk. However, as might be expected, they received a smaller proportion (12 per cent) of the total amount of milk delivered to homes. Households that were taking deliveries less than three times weekly would be expected to be the smaller families whose needs probably do not warrant three deliveries per week. Of the families that were getting one or two deliveries, 72.3 per cent included three members or less. (Average size of a West Virginia family was 3.51 in 1961)..$^{12}$

The retail route customers who were opposed to two deliveries weekly were also the customers who consumed the larger volumes of milk. These 400 households represented 58 per cent of the families that were getting home delivery. Also, they represented 69 per cent of the total volume of home delivered milk. Evidently the families that are the larger milk consumers are the ones most unwilling to make the change to twice-a-week delivery.

As mentioned earlier, a comparison was to be made between the Ashland, Kentucky, retail route area (which had experienced twice-aweek delivery) and the Wheeling, West Virginia, retail route area (which had not experienced twice-a-week milk delivery).

Apparently twice-a-week delivery had little effect on the retail route customers' attitudes concerning less frequent delivery. By combining those households that were taking milk deliveries less than three times weekly and those that indicated they would accept twice-weekly delivery, it was discovered that about 42 per cent of the households in both areas were not opposed to twice-weekly delivery. Likewise, both the Ashland and the Wheeling residents that indicated unwillingness to accept twice-weekly deliveries amounted to approximately 58 per cent of the households that were receiving home delivery (Table 21 ).

\section{Reasons for Non-Acceptance}

A comparison of respondents' replies in the two study markets, Ashland, Kentucky, and Wheeling, West Virginia, indicated little difference between the customers in the two areas in the reasons for non-acceptance of twice-a-week delivery or their proportion of all replies.

12U.S. Dept. of Commerce, Bureau of Census, 1960 Census of Population, PC(1), 50 B, West Virginia, p. 50-53. 
Table 21. Attitudes Toward Twice-A-Week Delivery, Ashland and WHEELING

\begin{tabular}{|c|c|c|c|c|}
\hline Response & Households & $\begin{array}{l}\text { Units Milk } \\
\text { Purchased }\end{array}$ & Households & $\begin{array}{l}\text { Units Milk } \\
\text { Purchased }\end{array}$ \\
\hline $\begin{array}{l}\text { Ashland: } \\
\text { Would not accept } \ldots \ldots \ldots \ldots \\
\text { Would accept } \ldots \ldots \ldots \\
\text { Households taking less than } \\
\text { three deliveries per week } \ldots \\
\text { No answer } \ldots . . . . . \\
\text { Total (getting home delivery) } \ldots\end{array}$ & $\begin{array}{c}\text { Number } \\
170 \\
65 \\
61 \\
3 \\
299 \\
\end{array}$ & $\begin{array}{r}\text { Quarts } \\
2,021 \\
560 \\
345 \\
2,926 \\
\end{array}$ & $\begin{array}{c}\text { Per Cent } \\
58 \\
22 \\
20 \\
100\end{array}$ & $\begin{array}{c}\text { Per Cent } \\
69 \\
19 \\
12 \\
100 \\
\end{array}$ \\
\hline $\begin{array}{l}\text { Wheeling: } \\
\text { Would not accept } \ldots \ldots \ldots \\
\text { Would accept } \ldots \ldots \\
\text { Households taking less than } \\
\text { three deliveries per week } \ldots \\
\text { No answer } \ldots \\
\text { Total (getting home delivery) }\end{array}$ & $\begin{array}{r}230 \\
81 \\
87\end{array}$ & $\begin{array}{r}2,451 \\
679 \\
418\end{array}$ & $\begin{array}{l}58 \\
20\end{array}$ & $\begin{array}{l}69 \\
19 \\
\\
12\end{array}$ \\
\hline $\begin{array}{l}\text { Ashland and Wheeling Combined: } \\
\text { Would not accept } \ldots \ldots \ldots \\
\text { Would accept } \ldots \\
\text { Households taking less than } \\
\text { three deliveries per week .... } \\
\text { No answer }\end{array}$ & $\begin{array}{l}400 \\
146\end{array}$ & $\begin{array}{r}4,472 \\
1,239 \\
749 \\
14 \\
\end{array}$ & $\begin{array}{l}58 \\
21 \\
21\end{array}$ & $\begin{array}{l}69 \\
19 \\
12\end{array}$ \\
\hline Total (getting home delivery) ... & 697 & 6,474 & 100 & 100 \\
\hline
\end{tabular}

${ }^{*}$ Less than 0.5 per cent.

In both areas, "need or desire for fresh milk" constituted almost 50 per cent of the reasons mentioned for not accepting twice-a-week delivery. The other answers were also quite similar for the two areas. Since there was only a slight difference in responses in the two study areas, the reasons for non-acceptance have been pooled and analyzed for both areas combined (see Table 22).

Of the 697 households that received home milk delivery, 42 per cent did not reject the idea of twice-a-week delivery. The remaining 58 per cent did reject the idea and indicated certain specific reasons why twicea-week milk delivery would not be acceptable.

The principal reason for refusing twice-a-week milk delivery was lack of milk freshness. Of the 400 respondents who indicated non-acceptance, 191 said that the home-stored milk would not be maintained in fresh condition when delivered only twice each week. These 191 households received about 30 per cent of the milk delivered to customers in this study. Other householders, 31 in number, indicated that with less frequent delivery the milk would actually spoil or "get old" before it could be consumed. Thus, among the 400 respondents, there were actually 222 , or 56 per cent who gave reasons for refusing twice-a-week milk delivery that were concerned with milk freshness or keeping quality. 


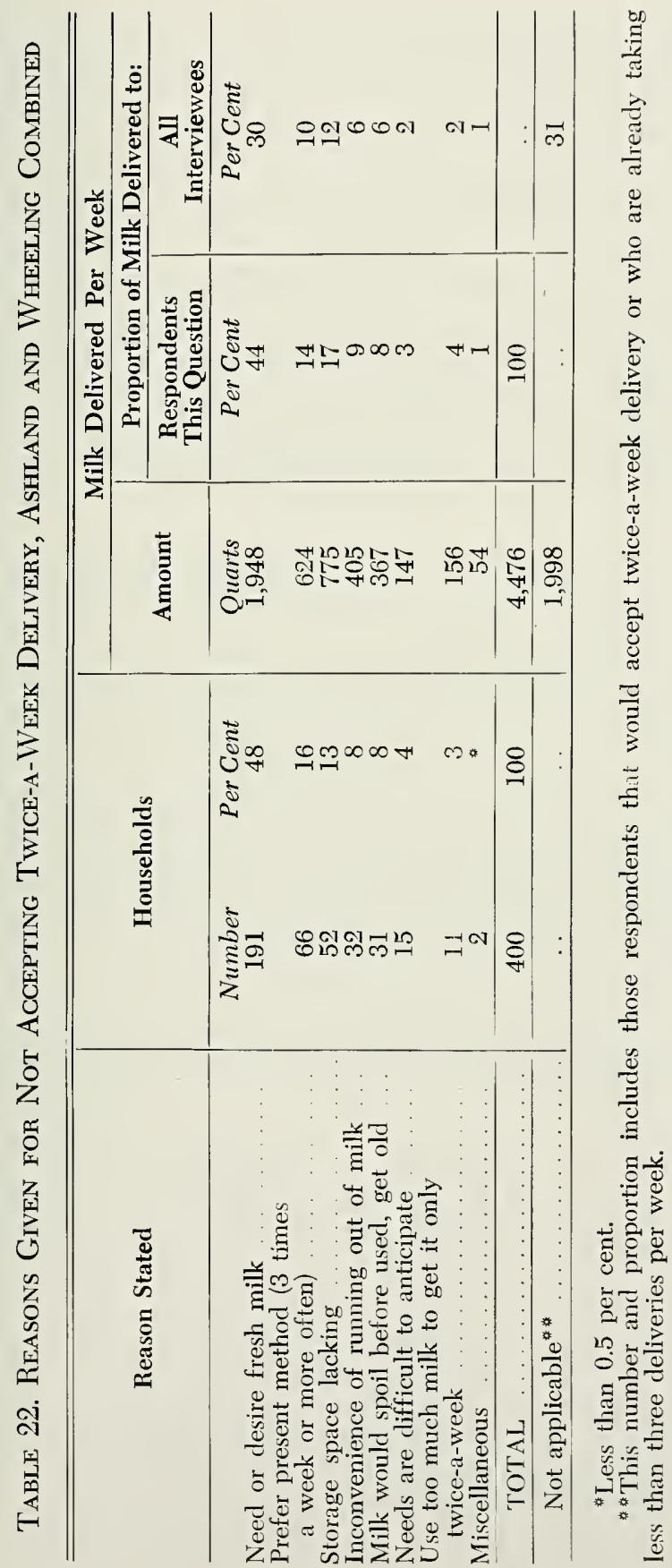


On the other hand, 94 per cent of the 148 respondents who were already receiving milk on less than three deliveries per week indicated that they had experienced no trouble with the keeping quality of their milk. Ninety-five per cent of these families who received milk less than three times per week described their milk quality as "excellent" or "good" while the remaining 5 per cent indicated that their milk was average in quality. None of the 148 householders who were getting less than three deliveries per week described their milk quality as being "below average" or "poor."

Consumer opinions about unsatisfactory milk freshness were thought to be based partially on long-standing experience. Conceivably these experiences had been with milk which was inadequately processed to reduce the bacteria count and with milk that had been stored under inadequate refrigeration. The older respondents, possibly, were recalling when it was not uncommon for milk to spoil within one day following delivery.

The data in Table 23 were tested to determine if there was any relationship between age and the frequency with which "milk freshness" was given as reason for non-acceptance. The chi-square test for significance indicated that the frequency with which this answer was given was significantly different for respondents over 55 years of age as compared with those 55 years of age and younger. ${ }^{13}$ Therefore, it is concluded that there was a relationship between age of the respondents and the frequency that "milk freshness" was given as a reason for non-acceptance.

These consumer opinions are understandable, but perhaps are not an accurate reflection of the keeping quality of milk currently sold in the market.

Table 23. Respondents' Ages and the Frequency that “NeEd or Desire Freshness" was Given as a Reason for Non-Acceptance

\begin{tabular}{|c|c|c|c|}
\hline $\begin{array}{l}\text { Age } \\
\text { Group }\end{array}$ & $\begin{array}{c}\text { "Milk Freshness" } \\
\text { Given As } \\
\text { Reason }\end{array}$ & $\begin{array}{c}\text { Other } \\
\text { Answers Given }\end{array}$ & $\begin{array}{c}\text { Total } \\
\text { All } \\
\text { Responses }\end{array}$ \\
\hline $\begin{array}{l}\quad \text { Years } \\
14-19 \\
20-24 \\
25-34 \\
35-44 \\
45-54 \\
55-64 \\
65 \text { and over }\end{array}$ & $\begin{array}{c}\text { Number } \\
6 \\
7 \\
51 \\
53 \\
24 \\
22 \\
28 \\
\end{array}$ & $\begin{array}{c}\text { Number } \\
6 \\
8 \\
59 \\
64 \\
37 \\
13 \\
22 \\
\end{array}$ & $\begin{array}{c}\text { Number } \\
12 \\
15 \\
110 \\
117 \\
61 \\
35 \\
50 \\
\end{array}$ \\
\hline TOTAL & 191 & 209 & $400^{*}$ \\
\hline
\end{tabular}

"Two "no answer" responses omitted.

${ }^{13}$ The computed value of chi-square was 4.8906. With one degree of freedom the tabular value is 3.84 at the .05 level. 
Returning to Table 22 , it was noted that 66 householders indicated that they "preferred the present method" (three-times-a-week). Ninety five per cent of these indicated that they could store the same quantity of milk if it was delivered twice a week. If the physical properties are present to make the change, and the only reason given was that of personal preference, possibly these personal preferences would be altered should the change to less frequent delivery be put into effect.

Of the householders who indicated that they would not be willing to accept twice-a-week milk delivery, 87 per cent did not indicate a lack of storage space to accommodate milk delivery less than three times a week. This 87 per cent received 83 per cent of the delivered milk.

Other reasons such as "inconvenient" and "needs difficult to anticipate" represent a relatively small proportion of the total reasons given as shown in Table 22.

\section{Fresh Fluid Milk Desired}

Respondents interviewed indicated that, in general, they would not be without fresh fluid milk should home delivery be discontinued. Sixhundred ninety-one of the 697 interviewees receiving home delivery indicated that they would obtain milk from another source. Only three respondents of the 697 indicated that they would omit fresh fluid milk from their diet. Three other householders gave no answer.

Of the 691 respondents who said they would not do without fresh fluid milk, 652 indicated that they would purchase their milk supply at a store. Thirty-two indicated "the supermarket" as the place of purchase. Four customers indicated "the dairy store" and two respondents said that they would buy a cow. One respondent gave no answer.

The three respondents who said that they would do without fresh fluid milk if delivery were discontinued would use juices or dried milk in place of fresh milk.

\section{Storage Space Analysis}

A change from three milk deliveries per week to twice-a-ıveek milk delivery would require the consumer to buy a greater volume of milk each delivery day. This greater volume would, in turn, require a larger amount of storage space than was needed with three deliveries per week.

The quantity of milk taken each delivery day on a twice-a-week basis should closely approximate 1.5 times as much milk as the consumer normally received each delivery day on the three-times-a-week system. Thus the two deliveries must provide the amount that was normally taken on the third delivery day in addition to the normal delivery amount. 
Each respondent was asked to indicate the number of units ${ }^{14}$ that he or she received on each delivery day. The enumerator selected the largest number of units delivered on any one day and increased it by one-half and rounded the answer to the next largest whole unit. This process indicated the amount of milk that each respondent needed to receive each delivery day if he shifted from three deliveries per week to twice-a-week delivery. Each householder was asked, "could you store (largest volume received any one day increased by one-half) of these units in your refrigerator if you received them all at one time?" In this manner it was determined whether or not a respondent had the storage facilities to accommodate twice-a-week delivery (Table 24 ).

Of the 697 respondents who received home delivered milk, 645 , or 93 per cent, indicated that they could store one-half again as much milk as they then received and stored at one time. The remaining 7 per cent said they could not store this much milk.

Table 24. Householders' Ability to Store 1.5 Times Their Largest Day's Quantity Delivered

\begin{tabular}{|c|c|c|}
\hline Response & Households & $\begin{array}{l}\text { Proportion } \\
\text { Of Total }\end{array}$ \\
\hline $\begin{array}{l}\text { Could Store } \\
\text { Could Not Store } \\
\text { No Answer ... }\end{array}$ & $\begin{array}{c}\text { Number } \\
645 \\
50 \\
2\end{array}$ & $\begin{array}{c}\text { Per Cent } \\
93 \\
7 \\
\star\end{array}$ \\
\hline TOTAL & 697 & 100 \\
\hline
\end{tabular}

${ }^{*}$ Less than 0.5 per cent.

Table 25. Estimated Quantities of Milk Customers Would Need to Take When Shifting from Three Deliveries Per Week to Two Per WEEK

\begin{tabular}{c|c|c}
\hline $\begin{array}{c}\text { Quantity } \\
\text { Needed }\end{array}$ & Households & $\begin{array}{c}\text { Proportion } \\
\text { Of Total }\end{array}$ \\
\cline { 1 - 2 } Quarts & Number & Per Cent \\
1 & 1 & 54 \\
2 & 373 & 32 \\
3 & 222 & 1 \\
4 & 7 & 7 \\
5 & 47 & 4 \\
6 & 31 & 0 \\
7 & 0 & 2 \\
8 & 15 & 0 \\
9 & 0 & 100 \\
\hline
\end{tabular}

${ }^{*}$ Less than 0.5 per cent.

${ }^{14}$ To the consumer, unit was explained to mean any size container in which he was then receiving milk. 
The estimated number of quarts (Table 2.5) that each consumer would need to receive each delivery day in order to change to twice-aweek delivery would seem relatively small. Five-hundred ninety-five or 85 per cent would need only three quarts or less delivered twice-a-week in order to obtain the same quantity of milk as delivered three times per week or more often. The remaining 101 householders or 15 per cent would need from four to eight quarts each delivery in order to make the change to twice-a-week delivery.

\section{Amount of Storage vs. Acceptance}

It was thought that there might be a positive relationship between the amount of storage space available (size of refrigerator) and acceptance or rejection of twice-a-week milk delivery. The data in Table 26 were tested to determine if there was any relationship between the cubicfoot-size rating of their refrigerator and acceptance of twice-a-week delivery. No significant difference existed between the individual's refrigerator storage capacity and whether or not he would accept twice-a-week delivery. ${ }^{15}$

Table 26. Size of Refrigerator and Acceptance or Rejection of Twice-A-Week Milk Delivery

\begin{tabular}{|c|c|c|c|c|c|}
\hline Size of Refrigerator & $\begin{array}{l}\text { Would } \\
\text { Accept }\end{array}$ & $\begin{array}{l}\text { Would } \\
\text { Not } \\
\text { Accept }\end{array}$ & $\begin{array}{c}\text { No Answer } \\
\text { or } \\
\text { Refused }\end{array}$ & $\begin{array}{l}\text { Would } \\
\text { Accept }\end{array}$ & $\begin{array}{l}\text { Would } \\
\text { Not } \\
\text { Accept }\end{array}$ \\
\hline $\begin{array}{l}\text { Cu.Ft. } \\
5 \\
6 \\
7 \\
8 \\
9 \\
10 \\
11 \\
12 \\
13 \\
14 \\
15 \text { and over } \\
\text { Don't know }\end{array}$ & $\begin{array}{c}\text { Number } \\
\cdot \\
3 \\
4 \\
13 \\
16 \\
25 \\
32 \\
22 \\
21 \\
8 \\
2\end{array}$ & $\begin{array}{c}\text { Number } \\
1 \\
9 \\
20 \\
25 \\
56 \\
40 \\
89 \\
52 \\
64 \\
32 \\
12 \\
2 \\
\end{array}$ & Number & $\begin{array}{c}\text { Per Cent } \\
2 \\
3 \\
9 \\
10 \\
17 \\
22 \\
15 \\
15 \\
51 \\
2\end{array}$ & $\begin{array}{c}\text { Per Cent } \\
: \\
2 \\
5 \\
6 \\
14 \\
10 \\
22 \\
13 \\
16 \\
8 \\
3 \\
1 \\
\end{array}$ \\
\hline TOTAL & 146 & 400 & 3 & 100 & 100 \\
\hline
\end{tabular}

*Less than 0.5 per cent.

\section{Other Factors Affecting Acceptance Family Size}

An investigation of the data in Table 27 indicated that the size of family influenced whether the twice-a-week delivery idea was accepted or rejected.

${ }^{15}$ The calculated chi square value was 2.3844 . The tabular chi square value for 2 degrees of freedom is 5.99 at the 0.05 level. 
Table 27. Family Size and A c ce p t a n ce of Twice-A-Week Milk DeLIVERY*

\begin{tabular}{c|c|c|c|c}
\hline \hline \multirow{2}{*}{ Size of Family } & \multicolumn{2}{|c|}{ Would Accept } & \multicolumn{2}{c}{ Would Not Accept } \\
\cline { 2 - 5 } & \multicolumn{2}{|c|}{ Households } & \multicolumn{2}{|c}{ Households } \\
\cline { 2 - 5 } & Number & Per Cent & Number & Per Cent \\
Three members or less ....... & 87 & 60 & 151 & 38 \\
More than three members .... & 59 & 40 & 249 & 62 \\
\hline TOTAL ... & 146 & 100 & 400 & 100 \\
\hline
\end{tabular}

* 148 households with less than three deliveries per week and three "no answers" not included.

Families with three members or less comprised 60 per cent of the total households that would accept twice-a-week delivery while the same category represented only 38 per cent of those who would reject the idea.

Of the families who would accept twice-a-week delivery, 40 per cent had more than three members; 62 per cent of the families that would refuse home delivery had more than 3 members. In general, the larger families seemed more likely to reject and the smaller families seemed to be more receptive to twice-a-week delivery.

\section{Number of Children in Family}

There seemed to be a tendency for families with two children or less to be more receptive to the idea of twice-a-week delivery.

Table 28 indicates that of the families that would accept twice-aweek delivery, 86 per cent had two children or less while 14 per cent had three or more children. In contrast, of the families that would reject twice-a-week delivery, 70 per cent had two children or less and 30 per cent had three or more children.

Table 28. Number of Children in the Family and Acceptance of Twice-A-WEek DeliverX *

\begin{tabular}{|c|c|c|c|c|}
\hline \multirow{2}{*}{ Children } & \multicolumn{2}{|c|}{ Would Accept } & \multicolumn{2}{|c|}{ Would Not Accept } \\
\hline & \multicolumn{2}{|c|}{ Households } & \multicolumn{2}{|c|}{ Households } \\
\hline \begin{tabular}{l}
\multicolumn{2}{c}{ Number } \\
Two children or less \\
Three or more
\end{tabular} & $\begin{array}{c}\text { Number } \\
125 \\
21\end{array}$ & $\begin{array}{c}\text { Per Cent } \\
86 \\
14 \\
\end{array}$ & $\begin{array}{c}\text { Number } \\
285 \\
115 \\
\end{array}$ & $\begin{array}{c}\text { Per Cent } \\
70 \\
30 \\
\end{array}$ \\
\hline TOTAL & 146 & 100 & 400 & 100 \\
\hline
\end{tabular}

"148 households with less than three deliveries per week and three "no answers" not included.

There was a significant difference between the number of children in the family and acceptance of the change to twice-a-week delivery. ${ }^{16}$

${ }^{16}$ Significant at the .05 level using chi square test. 


\section{Quantity of Milk Delivered}

Whether the respondent accepted or rejected the idea of twice-aweek milk delivery might have been influenced by the number of quarts that he had delivered each week. The data in Table 29 indicate that there was a significant difference between the number of quarts delivered and whether the respondent would accept twice-a-week milk delivery. ${ }^{17}$ The small-volume customers tended to be more receptive to less frequent milk deliveries than were the large-volume customers.

Table 29. Amount of Milk Delivered Per Week and Acceptance of Twice-A-Week Delivery*

\begin{tabular}{|c|c|c|c|c|}
\hline \multirow{2}{*}{$\begin{array}{c}\text { Amount of } \\
\text { Milk Delivered }\end{array}$} & \multirow{2}{*}{\multicolumn{2}{|c|}{$\begin{array}{c}\text { Would Accept } \\
\text { Households }\end{array}$}} & \multirow{2}{*}{\multicolumn{2}{|c|}{$\frac{\text { Would }}{\text { Households }}$}} \\
\hline & & & & \\
\hline 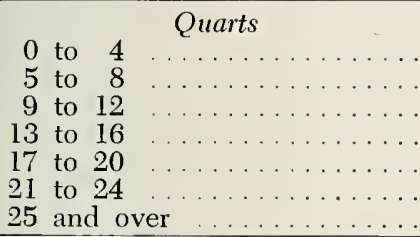 & $\begin{array}{c}\text { Number } \\
36 \\
47 \\
49 \\
8 \\
3 \\
3 \\
0\end{array}$ & $\begin{array}{c}\text { Per Cent } \\
25 \\
32 \\
34 \\
5 \\
2 \\
2 \\
0\end{array}$ & $\begin{array}{c}\text { Number } \\
53 \\
107 \\
129 \\
48 \\
28 \\
32 \\
3\end{array}$ & $\begin{array}{c}\text { Per Cent } \\
13 \\
27 \\
32 \\
12 \\
7 \\
8 \\
1\end{array}$ \\
\hline TOTAL & 146 & 100 & 400 & 100 \\
\hline
\end{tabular}

* 148 households with less than three deliveries per week and three "no answers" not included.

\section{Weekly Family Income}

The amount of income received weekly might also have had an influence on the acceptance of twice-a-week milk delivery. The data in Table 30 indicated that 45 per cent of those who accepted less frequent delivery received less than $\$ 100$ weekly while only 28 per cent of the

Table 30. Family Income Level and Acceptance of Twice-Weekly Milk Deliverr ${ }^{*}$

\begin{tabular}{|c|c|c|c|c|}
\hline \multirow{2}{*}{ Weekly Incomes } & \multicolumn{2}{|c|}{ Would Accept } & \multicolumn{2}{|c|}{ Would Not Accept } \\
\hline & \multicolumn{2}{|c|}{ Households } & \multicolumn{2}{|c|}{ Households } \\
\hline $\begin{array}{l}\text { Under } \$ 50 \\
\$ 50-\$ 99 \\
\$ 100-\$ 149 \\
\$ 150-\$ 199 \\
\$ 200 \text { and over } \\
\text { No answer }\end{array}$ & $\begin{array}{c}\text { Number } \\
19 \\
46 \\
35 \\
18 \\
17 \\
11 \\
\end{array}$ & $\begin{array}{c}\text { Per Cent } \\
13 \\
32 \\
24 \\
12 \\
12 \\
7 \\
\end{array}$ & $\begin{array}{c}\text { Number } \\
31 \\
82 \\
146 \\
59 \\
48 \\
34 \\
\end{array}$ & $\begin{array}{c}\text { Per Cent } \\
8 \\
20 \\
37 \\
15 \\
12 \\
8 \\
\end{array}$ \\
\hline TOTAL & 146 & 100 & 400 & 100 \\
\hline
\end{tabular}

"148 households with less than three deliveries per week and three "no answers" not included.

${ }^{17}$ The calculated chi square for the data in Table 29 was 25.74. The tabular value was 12.59 for six degrees of freedom at the .05 level. 
respondents who refused twice-a-week delivery received less than $\$ 100$ a week. In contrast, 55 per cent of the customers who accepted less frequent delivery received $\$ 100$ or more a week compared to 72 per cent of those refusing twice-a-week delivery and who received $\$ 100$ or more a week. Thus, the lower income customers indicated greater acceptance of reducing delivery frequency than did the higher income families. This was thought to be due to a greater interest in lowering milk costs among the lower income families than among the higher income families.

\section{Milk Keeping Quality Adequate}

In general, milk keeping quality is adequate to support twice-a-week milk delivery. The keeping qualities of present-day, high-quality milk are such that in most cities it could now be safely delivered weekly-if the customer had the refrigerator facilities to store a week's supply of fresh milk. Properly refrigerated, today's milk will keep for well over a week. Passenger ships leaving New York for the trans-Atlantic voyage usually take enough fresh milk to last during both the out-going and the return voyage. New York fresh milk is regularly delivered in the Panama Canal Zone. $^{18}$

Weese and Henderson discovered that pasteurized milk would have a flavor score of 38 (good) after four days when used under normal home conditions. Their study indicated that milk which was pasteurized (not pasteurized-homogenized) would still be in a usable condition after six days under the customers' normal use. The results of this study are in Table 31 .

Table 31. Summary of the Flavor Scores of 207 Samples of Milk Left in 16 Home Refrigerators from 3 to 6 Days Under Summer Conditions

\begin{tabular}{|c|c|c|c|c|}
\hline \multirow{2}{*}{ Average Flavor Score } & \multicolumn{4}{|c|}{ Elapsed Time } \\
\hline & 3 Days & 4 Days & 5 Days & 6 Days \\
\hline Test Samples & 38.0 & 38.0 & 35.5 & 35.3 \\
\hline Control Samples & 39.2 & 39.0 & 38.2 & 38.8 \\
\hline
\end{tabular}

Source: S. J. Weese and H. O. Henderson, "The Keeping Quality of Pasteurized Milk in Home Refrigerators." Journal of Dairy Science, Nov, 1949, Vol. XXXII, No. 11, pp. 945-949.

*Key to Flavor Scores: 40-no criticisms; 38-40-slightly to moderately off flavor (good); 35-38-distinct off flavor, distinct absorbed flavor, unpalatable, but still usable (fair); 25-35-high acid, bitter, stale, old. Very pronounced off or absorbed flavor, generally not usable as a beverage (poor).

${ }^{18}$ Harold Fleming, Milkman's Economics. Milk Industry Foundation, 1145 I9th St., N.W., Washington 6, D.C., 1956, pp. 3-4. 
In a later study, Weese and Fike ${ }^{19}$ found that pasteurized milk and pasteurized-homogenized milk, when stored under normal home conditions, maintained a flavor score of good or higher and that it was still in a usable condition after six days following delivery (Figure 1).

Metzger and Taylor ${ }^{20}$ found that milk flavor will be of a very good quality under twice-a-week milk delivery. In a consumer test of keeping quality, they discovered that among 126 cooperators no off-flavors were reported during the first three days that milk was used. There was only one off-flavor reported on the fourth day. Thus, more than 99 per cent of the respondents indicated that their milk samples maintained acceptable quality and flavor for the maximum period that milk would be stored with twice-a-week delivery. Complete results are given in Table 32.

Table 32. Number and Percentage of Milk Samples with Off-Flavor After Specified Days Under Test*

\begin{tabular}{c|c|c|c}
\hline \hline \multirow{2}{*}{$\begin{array}{c}\text { Days Under } \\
\text { Test }\end{array}$} & Sample & \multicolumn{2}{|c}{ Samples Reported } \\
\cline { 2 - 4 } & & Off-Flavor & Good \\
\cline { 2 - 4 } & Number & Per Cent & Per Cent \\
2 & 126 & 0 & 100 \\
3 & 126 & 0 & 100 \\
4 & 124 & 0 & 100 \\
5 & 122 & 1 & 99 \\
6 & 116 & 1 & 99 \\
7 & 110 & 5 & 95 \\
8 & 88 & 5 & 95 \\
9 & 47 & 6 & 97 \\
10 & 34 & 3 & 93 \\
11 & 27 & 5 & 95 \\
12 & 21 & 6 & 94 \\
13 & 16 & 8 & 92 \\
14 & 13 & 13 & 25 \\
$15-21$ & 8 & 75 & 97 \\
\hline
\end{tabular}

* Source: H. B. Metzger and R. I. Taylor, Consumer Reaction to Reducing Deliveries on Retail Milk Routes in Houlton and Presque Isle, Maine. Misc. Rept. 101, Oct. 1961, Me. Agr. Exp. Sta., Orono, Me.

\section{Respondents' Experience with Milk Keeping Quality}

Of the 1,004 respondents interviewed, there were 960 , or 96 per cent, who indicated that they had experienced no difficulty with milk keeping quality during the previous year (1960). Only 4 per cent indicated that they had experienced trouble with milk keeping quality during this period. It would seem that the keeping quality of the milk used could be described as "excellent" ( Table 33).

${ }^{19}$ S. J. Weese and J. E. Fike, Some Aspects of Every-Other-Day Milk Delivery. Current Rept. 5, Aug., 1953. W. Va. Agr. Exp. Sta., Morgantown, W. Va.

${ }^{20}$ H. B. Metzger and R. 1. Taylor, Consumer Reaction to Reducing Deliveries on Retail Milk Routes in Houlton and Presque Isle, Maine. Misc. Rept. 101, Oct., 1961. Me. Agr. Exp. Sta. Orono, Me. 


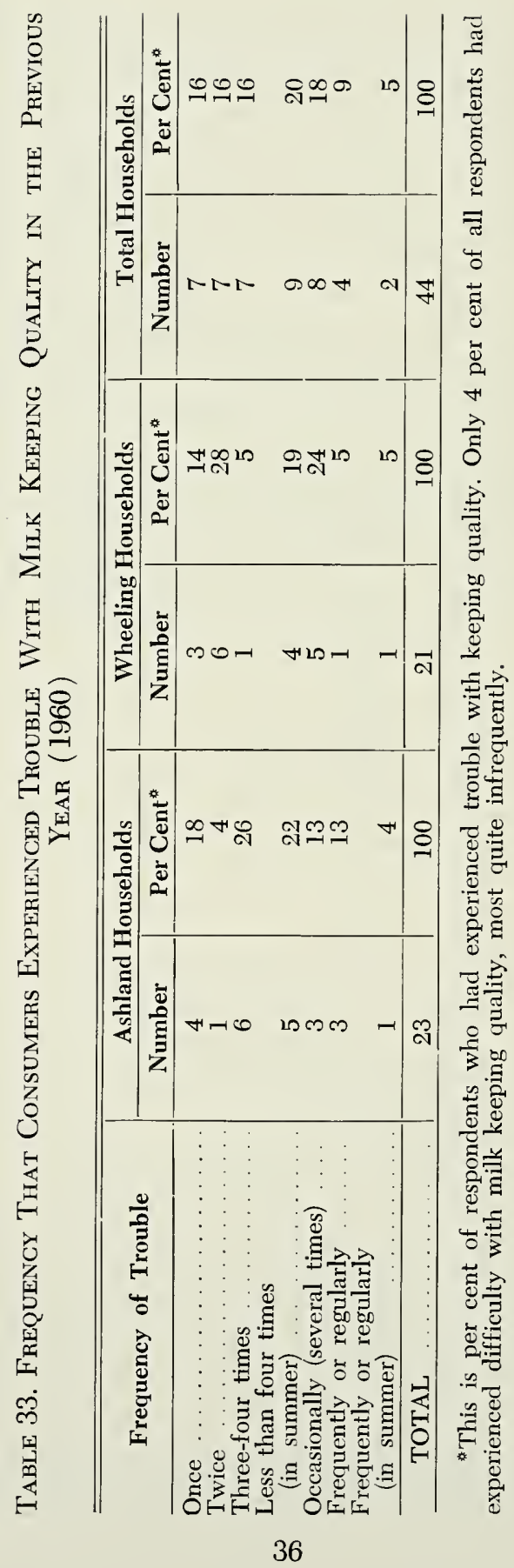


Table 34. Trouble Experienced with Milk Keeping Quality in the Previous Year (1960)

\begin{tabular}{l|c|c|c|c|c|c}
\hline \hline Experience With & \multicolumn{2}{|c|}{ Ashland Households } & \multicolumn{2}{|c|}{ Wheeling IHouseholds } & \multicolumn{2}{|c}{ Total Households } \\
\cline { 2 - 6 } Keeping Quality & Number & Per Cent & Number & Per Cent & Number & Per Cent \\
\hline No trouble . . & 481 & 95 & 479 & 96 & 960 & 96 \\
Trouble & 23 & 5 & 21 & 4 & 44 & 4 \\
\hline TOTAL & 504 & 100 & 500 & 100 & 1,004 & 100 \\
\hline
\end{tabular}

A comparison of markets studied indicated that there was little difference in the per cent of respondents that had experienced trouble with milk keeping quality as indicated by Table 34 .

Of the 1,004 respondents, 932 , or 93 per cent, indicated that they had satisfactorily stored milk three days or more. Seventy-six per cent of the consumers indicated that they had successfully stored milk four or more days. In general, most consumers had stored milk more than three days, the storage time required to support twice-a-week delivery (Table $35)$.

Each respondent was asked to indicate the number of days that he usually stored milk. Sixty-five per cent indicated that they usually kept milk two days or less before it was completely consumed. Thirty-five per cent indicated that they usually stored milk three or more days before it is consumed. Thus, 35 per cent of the respondents were already storing milk long enough to support twice-a-week milk delivery (Table 35).

In addition, each householder was asked to indicate the number of days that he preferred to store milk. Sixty-six per cent of the respondents

Table 35. Time Periods Consumers: Have Stored Milk, Usually Store Milk, and Prefer to Store Milk, Ashland and Wheeling Comibined

\begin{tabular}{|c|c|c|c|c|c|c|}
\hline $\begin{array}{l}\text { Storage } \\
\text { Period }\end{array}$ & \multicolumn{2}{|c|}{$\begin{array}{l}\text { Period Milk Has Been } \\
\text { Stored Satisfactorily }\end{array}$} & \multicolumn{2}{|c|}{$\begin{array}{l}\text { Period Consumers } \\
\text { Usually Keep Milk }\end{array}$} & \multicolumn{2}{|c|}{$\begin{array}{l}\text { Period Consumers } \\
\text { Prefer to Keep Milk }\end{array}$} \\
\hline Days & Hou & holds & Hous & holds & Hou & oolds \\
\hline $\begin{array}{r}0 \\
1 \\
2 \\
3 \\
4 \\
5 \\
6 \\
7 \\
8 \\
9 \\
\text { over } 9 \\
\end{array}$ & $\begin{array}{c}\text { Number } \\
17 \\
3 \\
52 \\
170 \\
236 \\
164 \\
60 \\
221 \\
31 \\
50 \\
.\end{array}$ & $\begin{array}{c}\text { Per Cent } \\
2 \\
\\
5 \\
17 \\
24 \\
16 \\
6 \\
22 \\
3 \\
5\end{array}$ & $\begin{array}{c}\text { Number } \\
1 \\
88 \\
560 \\
209 \\
63 \\
19 \\
18 \\
45 \\
0 \\
1\end{array}$ & $\begin{array}{c}\text { PerCent } \\
* \\
9 \\
56 \\
21 \\
6 \\
2 \\
2 \\
4 \\
.\end{array}$ & $\begin{array}{c}\text { Number } \\
3 \\
82 \\
576 \\
227 \\
53 \\
19 \\
18 \\
25 \\
0 \\
1\end{array}$ & $\begin{array}{r}\text { Per Cent } \\
8 \\
8 \\
57 \\
23 \\
5 \\
2 \\
2 \\
3 \\
\cdot\end{array}$ \\
\hline TOTAL & 1,004 & 100 & 1,004 & 100 & 1,004 & 100 \\
\hline
\end{tabular}

${ }^{\circ}$ Less than 0.5 per cent. 
indicated that they preferred to store milk two days or less. The remaining 34 per cent indicated that they preferred to keep milk three days or more. As a matter of preference, the majority of the consumers would rather keep milk two days or less. This preference would definitely not be compatible with less than three milk deliveries each week (Table 35).

\section{Market Comparison}

An investigation of Tables 36 and 37 indicated that there was only a slight difference in the two markets studied concerning (a) the most days consumers have stored milk satisfactorily, (b) the number of days that consumers usually store milk, and (c) the number of days that the consumers prefer to store milk.

There seemed to be a slightly higher percentage of customers that have stored milk more than four days in Ashland than in Wheeling. One explanation for this might be that the respondents in the Ashland area had stored milk a bit longer because they had experienced twice-a-week delivery which requires storage for longer periods.

There was a slightly higher percentage of respondents in Wheeling who usually stored milk and preferred to keep milk less than four days than there were in Ashland. This also might be due to the fact that the Ashland customers had become more accustomed to storing milk a little longer than Wheeling residents because of their trial exposure to twice-aweek delivery.

Table 36. Periods Consumers: Have Stored Milk, Usually Store Milk, and Prefer to Store Milk in Ashland, Kentucky

\begin{tabular}{|c|c|c|c|c|c|c|}
\hline $\begin{array}{l}\text { Storage } \\
\text { Period }\end{array}$ & \multicolumn{2}{|c|}{$\begin{array}{l}\text { Period Milk Has Been } \\
\text { Stored Satisfactorily }\end{array}$} & \multicolumn{2}{|c|}{$\begin{array}{l}\text { Period Consumers } \\
\text { Usually Keep Milk }\end{array}$} & \multicolumn{2}{|c|}{$\begin{array}{l}\text { Period Consumers } \\
\text { Prefer to Keep Milk }\end{array}$} \\
\hline Days & \multicolumn{2}{|c|}{ Households } & \multicolumn{2}{|c|}{ Households } & \multicolumn{2}{|c|}{ Households } \\
\hline $\begin{array}{l}0 \\
1 \\
2 \\
3 \\
4 \\
5 \\
6 \\
7 \\
8 \\
9\end{array}$ & $\begin{array}{c}\text { Number } \\
10 \\
1 \\
21 \\
73 \\
106 \\
77 \\
32 \\
28 \\
24 \\
32 \\
\end{array}$ & $\begin{array}{c}\text { Per Cent } \\
2 \\
\\
4 \\
15 \\
21 \\
15 \\
6 \\
26 \\
5 \\
6 \\
\end{array}$ & $\begin{array}{c}\text { Number } \\
1 \\
51 \\
256 \\
113 \\
31 \\
10 \\
13 \\
29 \\
\ldots \\
\ldots \\
\end{array}$ & $\begin{array}{c}\text { Per Cent } \\
10 \\
51 \\
22 \\
6 \\
2 \\
3 \\
6 \\
\ldots \\
\ldots \\
\end{array}$ & $\begin{array}{c}\text { Number } \\
3 \\
44 \\
271 \\
119 \\
30 \\
16 \\
10 \\
12 \\
\ldots \\
\ldots \\
\end{array}$ & $\begin{array}{c}\text { Per Cent } \\
1 \\
9 \\
53 \\
24 \\
6 \\
3 \\
2 \\
2 \\
\cdots\end{array}$ \\
\hline TOTAL & 504 & 100 & 504 & 100 & 504 & 100 \\
\hline
\end{tabular}

${ }^{*}$ Less than 0.5 per cent. 
Table 37. Periods Consumers: Have Stored Milk, Usually Store Milk, and Prefer to Store Milk in Wheeling, West Virginia

\begin{tabular}{|c|c|c|c|c|c|c|}
\hline $\begin{array}{c}\text { Storage } \\
\text { Period }\end{array}$ & \multicolumn{2}{|c|}{$\begin{array}{c}\text { Period Milk Has Been } \\
\text { Stored Satisfactorily }\end{array}$} & \multicolumn{2}{|c|}{$\begin{array}{l}\text { Period Consumers } \\
\text { Usually Keep Milk }\end{array}$} & \multicolumn{2}{|c|}{$\begin{array}{l}\text { Period Consumers } \\
\text { Prefer to Keep Milk }\end{array}$} \\
\hline Days & \multicolumn{2}{|c|}{ Households } & \multicolumn{2}{|c|}{ Households } & \multicolumn{2}{|c|}{ Households } \\
\hline 0 & Number & Per Cent & Number & Per Cent & Number & Per Cent \\
\hline 1 & 2 & & 37 & 7 & 38 & 7 \\
\hline 2 & 31 & 6 & 304 & 61 & 305 & 61 \\
\hline 3 & 97 & 19 & 96 & 20 & 108 & 21 \\
\hline 4 & 130 & 26 & 32 & 6 & 23 & 5 \\
\hline 5 & 87 & 18 & 9 & 2 & 4 & 1 \\
\hline 6 & 28 & 6 & 5 & $\overline{1}$ & 8 & 2 \\
\hline $\begin{array}{l}7 \\
8\end{array}$ & $\begin{array}{r}93 \\
7\end{array}$ & 19 & 16 & 3 & 13 & 3 \\
\hline 9 & 18 & 4 & 1 & 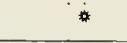 & $i$ & \% \\
\hline TOTAL & 500 & 100 & 500 & 100 & 500 & 100 \\
\hline
\end{tabular}

${ }^{*}$ Less than 0.5 per cent.

\section{Analysis of Distributor Attitudes and Opinions}

In February and March of 1963, a survey of dealer attitudes toward and potential efficiencies from twice-weekly delivery of milk to homes was made throughout West Virginia. Representatives of all but a few of the dairies in the State that had retail delivery to homes were interviewed. The 53 dealers interviewed were separated into two groups as follows: the processor-distributor, or distributor group (Group A); and the producer-processor-distributor group (Group B). There were 47 dealers in Group A and 6 dealers in Group B. The initial questions asked were designed to determine the status of retail operations in the state as well as to indicate what change the retail milk business has gone through in the past ten years.

In Group A, retail delivery to homes constituted 44 per cent of the milk sales. Group B's average was 57 per cent, which stresses the fact that many of the smaller dealers are still very dependent upon retail sales. Table 38 relates the number of distributors with the proportion of total sales made by retail home delivery.

\section{Retail Route Sales Declining}

When asked if the percentage of their sales through retail delivery had changed substantially in the last five years, 35 of Group A said yes, while only 2 of Group B said yes. There were 24 dealers in Group A who showed a decrease in the percentage of their retail sales and only 11 that showed an increase. The two dairies in Group B that showed substantial change in the last five years experienced decreases. 
Table 38. Number and Proportion of Distributors by Proportion of Milk Sales Made by Retail Delivery

\begin{tabular}{|c|c|c|c|c|}
\hline \multirow{2}{*}{$\begin{array}{c}\begin{array}{c}\text { Proportion of Sales } \\
\text { By Retail Delivery }\end{array} \\
\text { Per Cent } \\
0-9\end{array}$} & \multicolumn{2}{|c|}{$\begin{array}{c}\text { Processor-Distributors } \\
\text { Group A }\end{array}$} & \multicolumn{2}{|c|}{$\begin{array}{c}\text { Producer-Processor- } \\
\text { Distributors } \\
\text { Group B }\end{array}$} \\
\hline & Number & Per Cent & Number & Per Cent \\
\hline $10-19$ & 4 & $\begin{array}{r}17.02 \\
8.51\end{array}$ & 2 & 33.33 \\
\hline $20-29$ & 4 & 8.51 & 1 & 16.67 \\
\hline $30-39$ & 5 & 10.64 & & \\
\hline $40-49$ & 7 & 14.89 & & \\
\hline $50-59$ & 4 & 8.51 & & \\
\hline $60-69$ & 9 & 19.15 & & \\
\hline $70-79$ & 2 & 4.26 & & \\
\hline $80-89$ & 2 & 4.26 & 1 & 16.67 \\
\hline $90-100$ & 2 & 4.26 & 2 & 33.33 \\
\hline TOTAL & 47 & 100.00 & 6 & 100.00 \\
\hline
\end{tabular}

In the last ten years 29 of 37 dealers in Group A, or 78 per cent, reported a substantial change in the percentage of their sales through retail delivery. As was the case during the most recent 5 -year period, about 31 per cent of the dealers reporting a change had increases, while 69 per cent had decreases.

The dealers in Group B responded for the 10-year period just as they had for the 5-year period. Two indicated a change, both showing decreases in percentage of sales through retail delivery.

\section{Reasons for Decline}

Reasons given by the dealers which accounted for the decreases in the percentage of their sales through retail delivery were classified into four groups and are listed in order of the frequency reported:

1. The public's attraction to the convenience and availability of retail stores, particularly supermarkets, and aggressive selling by supermarkets, including using milk as a "loss-leader" item;

2. The lack of ability and initiative on the part of retail routemen (drivers) and the lack of a good retail promotion program;

3. An emphasis on wholesale selling;

4. The reduction of delivery frequency, more competition from large dairies, and other reasons.

The first category of reasons listed above received more than six times the number of responses any of the other categories received.

Dealers noting an increase in percentage of sales through retail delivery indicated that the following categories of reasons were responsible:

1. More emphasis on retail sales;

2. The expansion of overall business and growth of the company; 
3. An increase in population, in service, and in consumer acceptance of the service provided.

Each of these reasons received were given by about the same number of respondents.

\section{Characteristics of Retail Routes}

The 47 distributors in the processor-distributor group (Group A) operated 377 retail and combination retail-wholesale milk routes. These routes delivered primarily to homes, although more than half were combination retail-wholesale routes. In the producer-processor-distributor group (Group B), the six distributors operated 10.5 routes. All but one of these routes were combination routes.

A route was considered to be the week's work of one routeman plus his relief routeman. Where less than four deliveries were made per customer per week, such as three times weekly, the two delivery segments served constituted one route.

Comparison of size of retail operations among the various dairies is difficult because of the varied operations followed by them. However, using the number of both retail and combination retail-wholesale routes employed by each distributor as a common denominator, classification by size of operation is possible. Table 39 shows the distribution of the milk distributors based on the number of retail and combination routes operated. In Group A, over 74 per cent of the distributors had eight routes or less. In Group B, as would be expected, all of the dealers were in the first category of four routes or less.

\section{General Delivery Practices}

At the time the processor-distributor group (Group A) was surveyed, several delivery frequencies were in operation throughout West Virginia.

Table 39. Number and Proportion of Distributors, by Number of Retail and Combination Retall-IVholesale Routes Operated

\begin{tabular}{|c|c|c|c|c|c|c|}
\hline $\begin{array}{l}\text { Routes } \\
\text { Operated }\end{array}$ & \multicolumn{2}{|c|}{$\begin{array}{c}\text { Processor-Distributors } \\
\text { Group A }\end{array}$} & \multicolumn{2}{|c|}{$\begin{array}{l}\text { Producer-Processor- } \\
\text { Distributors } \\
\text { Group B }\end{array}$} & \multicolumn{2}{|c|}{$\begin{array}{c}\text { Total } \\
\text { Distributors }\end{array}$} \\
\hline $\begin{array}{l}4 \text { or less } \\
5-9 \\
10-14 \\
15-19 \\
20-24 \\
25-30 \\
31-34 \\
35-39\end{array}$ & $\begin{array}{c}\text { Number } \\
17 \\
18 \\
5 \\
3 \\
3 \\
\cdots \\
1\end{array}$ & $\begin{array}{c}\text { Per Cent } \\
36.17 \\
38.30 \\
10.64 \\
6.38 \\
6.38 \\
\ldots \\
2.13\end{array}$ & $\begin{array}{c}\text { Number } \\
6 \\
- \\
- \\
- \\
- \\
- \\
- \\
-\end{array}$ & $\begin{array}{c}\text { Per Cent } \\
100.00 \\
\ldots \\
\ldots \\
\ldots \\
\ldots \\
\ldots \\
\ldots\end{array}$ & $\begin{array}{c}\text { Number } \\
23 \\
18 \\
5 \\
3 \\
3 \\
\cdots \\
1\end{array}$ & $\begin{array}{c}\text { Per Cent } \\
43.40 \\
33.96 \\
9.43 \\
5.66 \\
5.66 \\
\ldots\end{array}$ \\
\hline TOTAL & 47 & 100.00 & 6 & 100.00 & 53 & 100.00 \\
\hline
\end{tabular}

'Total routes operated were 377 . 
Delivery to homes three times per week was the most predominant, and accounted for 52 per cent of the 377 retail routes surveyed. Thirty-seven per cent of the routes operated on a five-day schedule, with one group of customers receiving deliveries three times per week, and another group twice-a-week delivery. Five per cent of the routes were operated five times per week and 2 per cent six times per week. There were 13 routes (or over 3 per cent), which operated on an alternate-delivery-week basis. Eleven of the thirteen routes delivered products four times one week and three times the next week. Two routes delivered products three times one week and twice the next week.

All 47 dealers in the group made deliveries either three times per week or on the split five-day delivery system in which some customers get three deliveries and other customers only two deliveries weekly. The split five-day delivery system was used predominantly in some of the larger cities, namely, Charleston, Parkersburg, Clarksburg, and Beckley, although the smaller cities of Logan and Pt. Pleasant also had this type of delivery service. Of the 13 dealers who had this service in operation, only one used it on a limited basis. The methods by which the dealers determined who was to receive twice-a-week delivery on the three- and two-delivery system varied. Most often the dealers would try to provide the large-volume-customer areas with three deliveries per week and the small-volume-customer areas with twice-a-week service. Some distributors made exceptions to the arrangement, serving large-volume customers in the twice-a-week areas with three deliveries per week. Others, however, made no exceptions, once the delivery areas were initially determined. Another method placed the low-income sections of the city on twice-aweek service. Geographic location often determined whether a customer would receive two or three deliveries per week. The rural areas frequently accounted for much of the distributors' twice-a-week business.

The practice of the producer-processor-distributor group differed from those of Group A considerably. Six and one-half of the 10.5 routes, or 62 per cent, delivered to homes three times a week. Three routes were operated on a four-deliveries-per-week basis, and one route made deliveries six days per week. The more frequent deliveries by the Group B dairies, as well as by some of the smaller distributors in Group A, in many cases were the result of using increased service to counteract the many services and by-products that the large distributors provided.

\section{Frequency and Volume of Delivery to Customers}

The frequency of delivery of the various routes was not always a good indicator of exactly how the customers received their deliveries. In 
the processor-distributor group although nearly 73 per cent of the retail routes were scheduled to make three deliveries per week, only slightly over 71 per cent of the customers received delivery this frequently. In contrast, 74 per cent of the retail volume was delivered three times per week. The proportion of route operations and actual customer deliveries on a twice-a-week delivery basis were almost identical, about 18 per cent, but the distributors estimated that only 15.5 per cent of the retail volume was delivered twice-weekly. While 5 per cent of the routes made five deliveries per week, only 3 per cent of the customers received delivery this frequently. However, approximately 4 per cent of the retail volume was delivered five times per week. The routes making six deliveries per week amounted to 2 per cent of the total routes. About 2.5 per cent of all retail customers received six deliveries per week and it was estimated by the distributors in Group A that approximately 2.5 per cent of their retail volume was made on routes with six deliveries per week. Another 5 per cent of the customers received milk at these or other frequencies which were not designated but only about 4 per cent of the volume was distributed in this manner.

A comparison of the producer-processor-distributor group's (Group B) distribution revealed similar differences. Although 62 per cent of the group's routes were operated three times per week, only 51 per cent of the retail customers received milk this frequently. Fifty-four per cent of Group B's retail volume was delivered at this frequency. Although there were no routes operating twice a week, over 16 per cent of the retail customers and almost 12 per cent of the retail volume were delivered twice-weekly. Four deliveries per week were made by 28.5 per cent of the routes, but these deliveries accounted for only 21 per cent of the customers and 24 per cent of the volume. The proportion of the routes and the proportion of the customers receiving six deliveries per week were both 9.5 per cent. However, only 8.5 per cent of the retail volume was delivered this frequently. Another 2 per cent of the customers received delivery at other frequencies and they received about 1.5 per cent of the volume delivered.

It is rather obvious from these comparisons that actual deliveries to the customers were not determined in many cases by the frequency with which the routes operated, but were adjusted to the customer needs on an individual basis. It was not unusual to find large-volume customers in areas normally receiving three deliveries per week who received five or six deliveries per week, and conversely, customers on routes making five or six deliveries per week who received only two or three deliveries per week. 
Table 40. Number of Retail Routes Operated Various Distances

\begin{tabular}{c|c|c|c|c}
\hline \hline $\begin{array}{c}\text { Route } \\
\text { Distance } \\
\text { Traveled }\end{array}$ & \multicolumn{2}{|c|}{$\begin{array}{c}\text { Processor-Distributors } \\
\text { Group A } \\
\text { Routes }\end{array}$} & \multicolumn{2}{|c|}{$\begin{array}{c}\text { Producer-Processor- } \\
\text { Distributors } \\
\text { Group B } \\
\text { Routes }\end{array}$} \\
\hline Miles & Number & Per Cent & Number & Per Cent \\
70 and over & 44.5 & 19.0 & 4.5 & 43.0 \\
$50-69$ & 41.5 & 17.0 & 2.5 & 24.0 \\
$30-49$ & 67.0 & 28.0 & 3.5 & 33.0 \\
Under 30 & 87.5 & 36.0 & 3.5 & 100.0 \\
\hline TOTAL & 240.5 & 100.0 & 10.5 & \\
\hline
\end{tabular}

\section{Distance Traveled Per Route}

Of the 47 milk distributors in Group A, 34 provided information on their route mileage. These 34 dealers ( 72 per cent of the total) accounted for 240.5 (or 65 per cent) of the 377 routes. In Group B, all 6 distributors, accounting for 10.5 routes, furnished the mileage information needed.

In Group A, an average distance of 43 miles was traveled per route per day. In the case of three deliveries weekly and the three and two (five-day operation) deliveries weekly, this distance represented the average distance traveled on the two segments of these routes. The average distance for Group B's routes was 49 miles.

Table 40 classifies the various routes by mileage intervals. In Group A, the processor-distributor group, 36 per cent of the routes were under 30 miles in length, while those from 30-49 miles accounted for 28 per cent of the total. Seventeen per cent of the routes were in the 50-69 mile range, and those over 70 miles in length accounted for almost 19 per cent of the routes. The longest distance traveled was 250 miles, while there were several routes operating less than 5 miles per day.

In Group B, 33 per cent of the routes were under 30 miles in length; 24 per cent were in the $30-49$ mile range; and routes over 70 miles in length accounted for 43 per cent of the total. The longest distance traveled was 90 miles, the shortest distance 15 miles.

When calculated on a weekly basis, there was a considerable amount of mileage involved in servicing retail route customers. The average route distance was driven less than six times per week. (Routes giving customers three deliveries per week are operated six times per week; routes on the three and two (five-day operation) deliveries per week system are operated five times per week).

\section{Attitudes Concerning Reduced Delivery Service}

Each of the 53 distributors was asked his opinion concerning the feasibility of both complete and partial adoption of twice-weekly delivery service on his delivery routes. 


\section{Feasibility of Complete Adoption}

Thirteen ( 28 per cent) of the 47 dealers in the processor-distributor group said that, in their opinion, reducing service to twice-weekly delivery for all their customers would be feasible. Only one of the six dealers in the producer-processor-distributor group also agreed that such a reduction was feasible.

The dealers who thought that twice-weekly delivery service was not feasible ( 34 dealers in Group A, 5 dealers in Group B) mentioned seven classes of reasons for its unfeasibility. Customers' lack of home storage space was the most frequently mentioned reason expressed by 19 dealers in Group A and by four dealers in Group B. Eighteen dealers in A and one in B said that such a shift would result in the loss or destruction of their retail sales. Difficulty in plant storage and scheduling of deliverymen and trucks were among the third class of reasons mentioned-by nine dealers, seven and two dealers in Groups A and B, respectively. Eight dealers in Group A and one in Group B were concerned about disrupting the deliveryman-customer relations and depriving customers of service which is important in maintaining retail sales. Six distributors in Group A indicated they were convinced that twice-a-week delivery would not be feasible based on experience from trials they had made. Six dealers, five in Group A and one in Group B, were convinced that the storage life of milk would not permit reducing the delivery frequency. Finally, four dealers, all in Group A, said other dealer competition would not permit such a reduction.

When the question on the feasibility of complete adoption was initially answered, 13 of the dealers in Group A and one in Group B said they thought that it was feasible. However, when asked why they felt it was feasible, many seemed to hedge on their initial answers. Almost half of the distributors said that they would have reservations about reducing deliveries. Several more said that it would be feasible, but only with the use of large-volume home dispensers. Nonetheless, the remainder were thoroughly convinced that it would be feasible either because of the probability of sharp reductions in overall delivery costs, or because better processing methods, as well as improved home, truck, and plant refrigeration, have considerably extended the useful life of the product.

\section{Feasibility of Partial Adoption}

The possibility of partial conversion to twice-iveekly service was explored by asking the dealer to specify the size of the customer order below or above which twice-weekly delivery would be feasible. The responses by distributors in Group A indicated that 60 per cent thought that some customers could be served twice weekly, while 40 per cent 
said that there was no volume which would permit this reduction in service. In Group A, 17 per cent of the dealers believed that customers now receiving more than four quarts per delivery could adapt to twiceweekly service, almost 13 per cent placed the maximum volume at four quarts, over 6 per cent at three quarts, 19 per cent at two quarts, and only 4 per cent said that one quart per delivery was the maximum delivery volume that could be handled under twice-weekly delivery.

Few of the dealers in Group B were convinced of the feasibility of twice-a-week delivery. Only two (one-third) of the dealers thought that some customers could be served twice-weekly. One distributor believed that customers now receiving more than four quarts per delivery could change to delivery twice a week. Another distributor placed the maximum volume that could be handled at two quarts or less per delivery.

When these dealers were asked to indicate why they believed that twice-weekly service was not feasible for their customers, they reemphasized the reasons listed above, such as lack of home storage space, fear of loss of retail sales, etc. However, several other reasons were mentioned also. Several dealers said that it would be very difficult, if not impossible, to reorganize the routes to meet the reduced needs of the small volume customers, while maintaining more frequent delivery to the large volume customers. Many dealers feared the necessity of delivery to customers in the same areas at different intervals.

In order to investigate possible savings that might result from shifting to twice-a-week delivery, the dealers were asked several questions. The first dealt with estimation of retail delivery costs per quart of milk. Only six of the 47 distributors in Group A estimated this, and their estimates ranged from 1.75 cents per quart to 5.50 cents per quart. The average was 3.29 cents per quart. Two Group B distributors gave estimates of 2.0 and 5.0 cents per quart. Differences in cost accounting methods, the influence of combination routes on retail cost analysis, lack of knowledge of the cost figures of the firm, or simply lack of a cost analysis program were the main reasons why 87 per cent of the dealers did not estimate this cost.

The second question concerned estimation of the saving per quart which the dealers believed could be effected by shifting to twice-a-week delivery from three-times-a-week delivery. Again, very few estimates were made-two in Group A and one in Group B. The two estimates in Group A were .75 and .50 cents per quart. The Group B estimate was 1.0 cent per quart. Most of the dealers said that they could not estimate such a saving at all, having never considered twice-a-week delivery and that they were unaware of the factors that might be involved. One dealer believed that no savings would result. 


\section{Twice-Weekly Delivery Not Planned}

None of the 53 retail milk distributors in West Virginia had any plans at the time the survey was made to shift to twice-weekly delivery. However, the responses indicated various levels of thinking on the subject. In the processor-distributor group, nearly 45 per cent stated that they had never considered a shift to twice-weekly service. Almost 28 per cent had considered or experimented with this system but were not planning to use it. About one-fourth of the dealers already deliver two days per week on some routes and three days per week on others, but do not plan to shift entirely to a twice-weekly delivery system. Only one dealer has considered twice-a-week delivery seriously, but he had no immediate plans to use this system of delivery.

All six dealers in the producer-processor-distributor group said they had never considered shifting to twice-weekly service.

\section{Suggestions to Reduce Delivery Costs}

Since none of the dealers were contemplating shifts to twice-weekly delivery, they were asked to suggest other means which would reduce the costs of retail delivery of milk. Their answers varied considerably, with some dealers offering several suggestions while others could offer none. Only 12 dealers, eight of them in the processor-distributor group, failed to offer any suggestions. The 41 dealers who responded contributed 62 suggestions, which were grouped into four different classes. Thirty-six responses, or 58 per cent, suggested consolidation or reorganization of routes to reduce mileage and the time spent in delivery. The next most frequently mentioned suggestion was increasing of sales per customer, through offering of more dairy and other products on retail routes. Twelve responses were included in this class. Eight other suggestions made up the third class, namely, to increase customers served per route by means of improved driver training and through increased driver selling effort. Three dealers stressed more efficient utilization of route delivery equipment. There were three other suggestions which were not related to the four listed, or to one another.

\section{Analysis of Retail Delivery Costs}

The cost of retail route delivery is the largest single item in the gross margin between the producer price and the consumer price for fluid milk, accounting for 39.7 per cent of the total. ${ }^{21}$

Story ${ }^{22}$ found that selling and delivery costs accounted for 41 per cent of the marketing cost, while plant costs, container costs, and ad-

21J. R. Tedford and A. L. Domike, Efficiency of Milk Distribution in Rhode Island. Bull. 333, June, 1956. R.I. Agr. Exp. Sta., Kingston, R.I.

22Robert P. Story, Cost of Milk Distribution in Local Vermont Markets. Bull. 545, 194S. Vt. Agr. Exp. Sta., Burlington, Vt. 
ministrative costs accounted for the remaining 59 per cent. A study by Metzger ${ }^{23}$ indicated that selling and delivery costs accounted for approximately 50 per cent of the total marketing cost.

Although the cost of selling and delivery varies from dealer to dealer, the two largest components are always labor and truck cost. Story found that labor cost accounted for 67 per cent of the selling and delivery cost, while truck costs were responsible for 26 per cent of the total.

Metzger found that delivery labor alone accounted for 38.4 per cent of the total marketing cost, while truck costs accounted for 12.2 per cent of the total.

Since labor costs and truck costs account for approximately 50 per cent of the total marketing costs and over 90 per cent of the selling and delivery costs, these two areas would be logical starting points for reducing delivery costs. This might be accomplished by improving either labor efficiency or truck efficiency or both.

Much of the variation in labor cost is a result of the different types of payment plans used by the dealers in paying the routemen for their services. These payment plans differ, not only among markets, but also among dealers within the same market. The plans most commonly used in paying the home delivery routemen are (1) the straight commission method, (2) the flat wage method, and (3) the combination wagecommission plan, consisting of a base salary plus a commission on the products sold. ${ }^{24}$

When the dealer pays the routemen by the straight commission payment plan or by the combination wage-commission plan it is very difficult to arrive at a sound estimate of the daily labor cost per route. However, when the flat wage plan is used to pay the routemen, it is relatively easy to estimate the daily labor cost per route.

Assuming a flat wage of $\$ 70.00$ per week for the routeman, Conner and Giles ${ }^{25}$ found that the salary for the routeman amounted to $\$ 11.67$ per day, or 77 per cent of the daily labor cost of operating a route. The remaining 23 per cent was accounted for by wages for the supervisor, vacation pay, social security payments, workmen's compensation payments, unemployment tax, hospitalization, laundry, bonus, and other perquisites.

Since the salaries for the routemen account for over three-fourths of the daily labor cost, the possibility exists for analyzing home delivery efficiency by examining the operations of the routemen. One possibility

\footnotetext{
${ }^{23}$ Homer B. Metzger, Changes in Costs of Milk Distribution in Maine, 1952-1953. Mimeo. Rept. No. 44, June, 1954. Me. Agr. Exp. Sta., Orono, Me.

${ }_{24}$ M. C. Conner and Edward J. Giles, Milk Delivery Practices-Alternatives and Costs. Bull. 515, July, 1960. Va. Agr. Exp. Sta., Blacksburg, Va.

${ }^{25}$ Ibid.
} 
for increasing labor efficiency is by increasing the volume delivered by the routemen utilizing the same amount of time. One study showed ${ }^{2 n}$ that the time required to deliver a single quart of milk at one stop was 3.3 seconds, whereas, it takes only 20 seconds per quart for two quarts, 15 seconds per quart for three quarts, 13 seconds per quart for four quarts, and only 9 seconds if seven or more quarts were delivered at one stop. Thus, assuming the same weekly volume, the use of two deliveries per week would increase delivery efficiency.

A more realistic approach based upon the total delivery operation, would be to deliver the same or greater quantities of milk in a given time utilizing fewer routemen. If a routeman were servicing two different home delivery routes three days a week (6-day week), and if the frequency of delivery were reduced from three deliveries per week to two deliveries per week, this same routeman could then service three different routes twice weekly (6-day week). This situation would apparently lead to a reduction in the number of routemen needed to service the total delivery operation. This reduction could conceivably be as great as one-third, thereby reducing the total amount paid as wages to the routemen. This reduction to twice-weekly delivery, based on the preceding assumptions, would reduce the labor cost per unit delivered, and thus: increase the efficiency of the delivery operation.

Truck costs, which accounted for the second largest proportion of delivery and selling costs, consist of fixed costs and variable costs. The fixed or overhead truck costs are the same regardless of the variable costs and the volume of output. Conner and Giles ${ }^{2 \pi}$ estimated that the overhead costs for a 1\%-ton refrigerated truck used in retail milk delivery were $\$ 2.60$ per day. Depreciation accounted for 71.5 per cent of the daily overhead truck costs, and insurance, interest on investment, license and taxes, and antifreeze accounted for the remaining 28.5 per cent of the total.

Variable truck costs are a function of miles traveled and time spent on the route. Conner and Giles ${ }^{25}$ found that the variable truck costs averaged 9.2 cents per mile on retail home delivery routes. Gasoline cost accounted for 57.6 per cent of the average variable truck costs, while oil, grease, tires, and repair and maintenance accounted for the remaining 42.4 per cent of the total.

Based upon a 37-mile delivery route, Conner and Giles ${ }^{29}$ found the total truck costs to be $\$ 6.00$ per day per route.

${ }^{26}$ James H. Clarke and Ancil B. Cutlip, "Time Required in Milk Delivery." In Science Serces Your Farm. Bull. 363, Part 3, Spring, 1954. W. Va. Agr. Exp. Sta., Morgantown, W. Va. 27 Conner and Giles, op. cit, p. 22.

${ }^{2}$ Ibid., p. 28.

29lbid., p. 33 . 
If one truck were being utilized to service two delivery routes three days a week (6-day week), and if the frequency of delivery were reduced to two deliveries per week with no reduction in the total volume delivered per week, the potential exists for reducing truck mileage by onethird, since the same truck could then be utilized to service three delivery routes twice weekly.

Assuming that the length of the route remained constant and that the delivery trucks presently in use have the capacity to carry the extra volume per day, a reduction to twice-weekly delivery introduces the possibility for reducing the number of trucks needed to service the entire delivery operation. This reduction, plus the reduction in mileage, would lower the total variable truck costs for the delivery operation as well as reducing depreciation costs, which accounted for 31 per cent of the total daily truck cost. ${ }^{30}$ These reductions would lower the total truck cost to the dealer, thus increasing the efficiency of the delivery operation.

Comparisons of the cost of delivery per unit under a three-times-perweek delivery plan and under a twice-weekly delivery plan were made. A study in Houlton, Maine, ${ }^{31}$ assumed a one-third reduction in truck mileage under twice-weekly delivery. Routemen in this study were paid on a base wage plus commission basis. Results of this study showed a delivery cost of 5.7 cents per unit delivered under a three-day delivery plan, and an estimated delivery cost of 4.7 cents per unit delivered under a twiceweekly delivery plan. Thus, a saving of one cent per quart would be realized in converting from three to two deliveries per week. Results of this study are summarized in Table 41.

Table 41. Specified Delivery Costs for a Retail Home Delivery Milk Route, Serving Customers on Three-Day and Two-Day a Week Delivery Schedules, Based on Route Data in Houlton, Maine, 1960

\begin{tabular}{l|c|c|c}
\hline \multicolumn{1}{c|}{ Items } & $\begin{array}{c}\text { Three-Day } \\
\text { Schedule }\end{array}$ & $\begin{array}{c}\text { Two-Day } \\
\text { Schedule }^{*}\end{array}$ & $\begin{array}{c}\text { Net } \\
\text { Change }\end{array}$ \\
\cline { 2 - 3 } $\begin{array}{c}\text { Daily Load } \\
\text { (Units) }\end{array}$ & 465 & 698 & +233 \\
$\begin{array}{c}\text { Daily Costs } \\
\text { Labor }\end{array}$ & $\$ 18.48$ & $\$ 24.25$ & $+\$ 5.77$ \\
Truck .... & 7.85 & 8.25 & $+\quad 0.40$ \\
$\quad$ Total . & $\$ 26.33$ & $\$ 32.50$ & $+\$ 6.17$ \\
Weekly Costs & $\$ 78.99$ & $\$ 65.00$ & $-\$ 13.99$ \\
Cost Per Unit & $\$ 0.057$ & $\$ 0.047$ & $-\$ 0.010$ \\
\hline
\end{tabular}

${ }^{*}$ Estimated.

* Routemen received base pay plus a commission for their services.

Source: Compiled from H. B. Metzger and James H. Clarke, Reducing the Frequency of Home Delivery of Milk, Table 10, p. 16.

30Ibid., Calculated from Table 12, p. 22.

${ }^{31}$ H. G. Metzger and James H. Clarke, Reducing the Frequency of Home Delivery of Milk. (A Northeast Regional Dairy Marketing Publication), Me. Agr. Exp. Sta., Bull. 637, Aug., 1965, Orono, Me. 
Table 42. Specified Delivery Costs for a Retall Home Delivery Milk Route, Serving Customers on Three-Day and Two-Day a Week Delivery Schedules, Based on Route Data in Danville and LynchBURg, Virginia, 1958

\begin{tabular}{|c|c|c|c|}
\hline Items & $\begin{array}{l}\text { Three-Day } \\
\text { Schedule }\end{array}$ & $\begin{array}{l}\text { Two-Day } \\
\text { Schedule }^{*}\end{array}$ & $\begin{array}{l}\text { Net } \\
\text { Change }\end{array}$ \\
\hline $\begin{array}{l}\text { Daily Load } \\
\text { (Units) }\end{array}$ & 462 & 692 & +230 \\
\hline Daily Costs & & & \\
\hline $\begin{array}{l}\text { Labor* } \\
\text { Truck }\end{array}$ & $\begin{array}{r}\$ 15.11 \\
6.00\end{array}$ & $\$ 16.50$ & $+\$ 1.39$ \\
\hline Total & $\$ 21.11$ & $\$ 22.50$ & - \\
\hline Weekly Costs & $\$ 63.33$ & $\$ 45.00$ & $-\$ 18.33$ \\
\hline Cost Per Unit & $\$ 0.046$ & $\$ 0.033$ & $-\$ 0.013$ \\
\hline
\end{tabular}

Estimated.

* * Routemen received a flat wage payment for their services.

Source: Compiled from M. C. Conner and E. J. Giles, Milk Delivery PracticesAlternatives and Costs, Table 18, p. 33.

A study in Danville and Lynchburg, Virginia, ${ }^{32}$ assumed no reduction in truck mileage under twice-weekly delivery. Routemen in this study were paid on a flat wage basis. Results of this study showed a delivery cost of 4.6 cents per unit delivered under a three-day delivery plan, and an estimated delivery cost of 3.3 cents per unit delivered under a twiceweekly delivery plan. Thus, a saving of one and three-tenths cents per quart would be realized in converting from three to two deliveries per week. Results of this study are summarized in Table 42.

A comparison of the Maine and Virginia studies showed that the estimated delivery cost per unit under a twice-weekly delivery plan in Maine ( 4.7 cents) slightly exceeded the cost of delivering a unit of milk in Virginia under a three-day-a-week delivery plan (4.6 cents). These data indicate that the cost of delivering a unit of milk on retail home delivery varies depending upon locality and the costs (including the plan used in paying the routeman for his services) applicable in the locality.

\section{Economic Implications}

In order to determine certain economic implications of reducing the trequency of retail home delivery from three days a week to two days a week, the results from the review of the preceding delivery cost studies were applied to the delivery operation of the dairy company which was analyzed earlier. To accomplish this, it was assumed that the dairy in Ashland had an average cost curve similar to the average cost curves of the plants in the Maine and Virginia studies and that all of the plants were operating at the same point on the average cost curve.

${ }^{32}$ Conner and Giles, op. cit., p. 32. 
Since the earlier results indicated that there was no significant change in the volume sold on a three-day-per-week delivery basis and the volume sold on a twice-weekly delivery basis, it was determined that the total quantity delivered would remain constant under a three-dayper-week delivery plan and under a twice-weekly delivery plan, during a specific year.

During the selected week in 1958, the dealer in Ashland, Kentucky, delivered 6,595 quart equivalents of fluid milk to the three-year customers, while operating on a three-day-per-week delivery basis. If this dealer had delivered milk on a twice-weekly frequency in 1958, and if he had based his delivery operation upon the assumptions of the Maine study, he could have reduced his delivery cost by one cent per quart equivalent, and thus, realized a delivery cost savings of $\$ 65.95$ from sales to the three-year customer, for the selected week (Table 43). If he had based his twice-weekly delivery upon the assumptions of the Virginia study, he could have saved one and three-tenths cents per quart equivalent, and thus, realized a delivery cost savings of $\$ 85.73$ from sales to the three-year customers for the selected week. Total sales to all retail customers during this week amounted to 13,782 quart equivalents of fluid milk. Thus, his possible retail delivery cost savings for all sales of fluid milk during the week would have ranged from $\$ 137.82$ to $\$ 179.16$.

During the selected week in 1959 , the same dealer delivered 6,494 quart equivalents of fluid milk to the three-year customers, while operating on a twice-weekly delivery basis. If his costs during that year were based on the same assumptions as in the Maine study, his delivery cost per quart equivalent for two deliveries would have been one cent below the cost of delivering three times per week. This probably would have re-

Table 43. Retail Home Delivery Costs for Two and Three Deliveries, Selected Week of October, Johnson's Dairy, Ashland, KENTUCKY, 1958

\begin{tabular}{c|c|c|c}
\hline \hline $\begin{array}{c}\text { Deliveries } \\
\text { Per Week }\end{array}$ & $\begin{array}{c}\text { Quantity } \\
\text { Delivered }\end{array}$ & $\begin{array}{c}\text { Cost Per Unit } \\
\text { Delivered }\end{array}$ & $\begin{array}{c}\text { Total Change } \\
\text { In Delivery } \\
\text { Costs }\end{array}$ \\
\hline Number & $\begin{array}{c}\text { Quart } \\
\text { Equivalent } \\
6,595\end{array}$ & Cents & Dollars \\
Three $\ldots \ldots \ldots \ldots \ldots$ & 6,595 & $\mathrm{X}_{1}^{*}$ & $\ldots$ \\
Twot $\ldots \ldots \ldots \ldots \ldots .95$ & $\left(\mathrm{X}_{1}-1.0\right)$ & -69.95 \\
Twot $\ldots \ldots \ldots \ldots \ldots$ & 6,595 & $\left(\mathrm{X}_{1}-1.3\right)$ & -85.73 \\
\hline
\end{tabular}

"Quantity in this column was assumed constant since the analysis of data showed no significant difference in the quantity purchased under twice-weekly delivery and the quantity purchased when three deliveries per week were offered. 1958.

${ }^{*} \mathrm{X}_{1}$ equals the delivery cost per unit on a three-delivery-per-week basis in

$\dagger$ Based on results from Table 41.

$\$$ Based on results from Table 42 . 
Table 44. Retall Home Delivery Costs for Two and Thiree Deliveries, Selected Week of October, Johnson's Dairy, Ashland, KentuCKY, 1959

\begin{tabular}{|c|c|c|c|}
\hline $\begin{array}{l}\text { Deliveries } \\
\text { Per Week }\end{array}$ & $\begin{array}{l}\text { Quantity } \\
\text { Délivered }\end{array}$ & $\begin{array}{c}\text { Cost Per Unit } \\
\text { Delivered }\end{array}$ & $\begin{array}{l}\text { Total Change } \\
\text { In Delivery } \\
\text { Costs }\end{array}$ \\
\hline 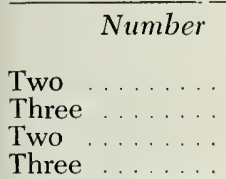 & $\begin{array}{c}\text { Quart } \\
\text { Equivalent } \\
6,494 \\
6,494 \\
6,494 \\
6,494\end{array}$ & $\begin{array}{c}\text { Cents } \\
\mathrm{Y}_{1}^{*} \\
\left(\mathrm{Y}_{1}+1.0\right) \\
\mathrm{Y}_{2}^{*} \\
\left(\mathrm{Y}_{2}+1.3\right)\end{array}$ & $\begin{array}{l}+64.94 \\
+84.42\end{array}$ \\
\hline
\end{tabular}

${ }^{*}$ Quantity in this column was assumed constant since the analysis of data showed no significant difference in the quantity purchased under twice-weekly delivery and the quantity purchased when three deliveries per week were offered.

${ }^{*} Y_{1}$ equals the delivery cost per unit on a twice-weekly delivery basis in 1959 , based on the results from Table 41 .

${ }^{*}{ }^{*} Y_{2}$ equals the delivery cost per unit on a twice-weekly basis in 1959 , based on the results from Table 42 .

sulted in a savings of $\$ 64.94$ from sales to the three-year customers for the selected week under twice-weekly delivery, as compared with what delivery costs would have been with three deliveries per week (Table 44). However, if its costs for twice-weekly delivery during 1959 were based on the same assumptions as the Virginia study, his cost of delivery per quart equivalent would have been one and three-tenths cents per quart below the cost of delivering three times per week. This would have resulted in a total savings of $\$ 84.42$ from sales to the three-year customers for the selected week under twice-weekly delivery. Total sales to all retail customers during this week amounted to 10,812 quart equivalents of fluid milk. Thus, its probable retail delivery cost savings for all sales of fluid milk during the week ranged from $\$ 108.12$ to $\$ 140.56$.

During 1960, the dairy studied again serviced its home delivery routes three times per week. It delivered 6,299 quart equivalents of fluid milk to the three-year customers during the selected week. If it had continued to service its routes twice-weekly under conditions outlined in the Maine plan, it could have saved one cent per quart and realized a total savings of $\$ 62.99$ from sales to the three-year customers during the selected week in 1960 (Table 45). If it had continued to service the retail routes twice-weekly under conditions described in the Virginia plan, it could have saved one and three-tenths cents per quart in delivery cost and realized a savings of $\$ 81.8 S$ from the sales to the three-year customers during the selected week. Total sales to all retail customers during this week amounted to 9,711 quart equivalents of fluid milk. Thus, its possible retail delivery cost savings for all sales of fluid milk during the week would have ranged from $\$ 97.11$ to $\$ 126.24$. 
Table 45. Retail Home Delivery Costs for Two and Three Deliveries, Selected Week of October, Johnson's Dairy, Ashland, KentuCKy, 1960

\begin{tabular}{|c|c|c|c|}
\hline $\begin{array}{l}\text { Deliveries } \\
\text { Per Week }\end{array}$ & $\begin{array}{l}\text { Quantity } \\
\text { Delivered }^{*}\end{array}$ & $\begin{array}{l}\text { Cost Per Unit } \\
\text { Delivered }\end{array}$ & $\begin{array}{l}\text { Total Change } \\
\text { In Delivery } \\
\text { Costs }\end{array}$ \\
\hline $\begin{array}{l}\text { Three } \\
\text { Twot } \\
\text { Two }\end{array}$ & $\begin{array}{c}\text { Quart } \\
\text { Equivalent } \\
6,299 \\
6,299 \\
6,299\end{array}$ & $\begin{array}{c}\text { Cents } \\
\mathrm{X}_{2}^{* *} \\
\left(\mathrm{X}_{2}-1.0\right) \\
\left(\mathrm{X}_{2}-1.3\right)\end{array}$ & $\begin{array}{r}\text { Dollars } \\
\\
-62.99 \\
-81.88\end{array}$ \\
\hline
\end{tabular}

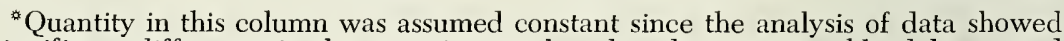
no significant difference in the quantity purchased under twice-weekly delivery and the quantity purchased when three deliveries per week were offered.

${ }^{* *} \mathrm{X}_{2}$ equals the delivery cost per unit on a three-delivery-per-week basis in 1960 .

† Based on results from Table 41 .

$\ddagger$ Based on results from Table 42 .

Thus, it was concluded that had the dairy studied delivered twiceweekly instead of three times per week in 1958, it could have saved from $\$ 137.82$ to $\$ 179.16$ during the selected week, depending upon the plan which was used as a basis for the twice-weekly delivery operation. In 1959 , the savings due to twice-weekly delivery ranged from $\$ 108.12$ to $\$ 140.56$ during the selected week, while in 1960 the estimated savings which would have resulted from twice-weekly delivery ranged from $\$ 97.11$ to $\$ 126.24$ for the selected week.

These data indicate that by reducing the frequency of delivery from three days per week to two days per week, the dealer had an estimated potential savings in excess of $\$ 7,000$ in $1958, \$ 5,500$ in 1959 , and $\$ 5,000$ in 1960 , respectively, as a result of reduced delivery costs.

What are the possible savings to consumers due to reducing the frequency of delivery? The dealer may choose to maintain his prices at the existing levels in an effort to increase his share of the market or he may lower them. If this happens, the consumer will benefit since prices will not have to be increased with rises in resource prices.

The dealer might choose to use a portion of these savings to increase the payments to the routemen, or he may be forced to do so. Routemen might resist reduction in commission payments per quart equivalent so that their relative share of the margin becomes greater despite the reduced time required to deliver larger volumes to each customer (each stop), which would occur under the twice-weekly delivery system.

In the opinion of the authors, the dealer would probably keep a portion of the savings as profit, use a portion to increase the wages of the routemen, and use the remainder to hold prices at the existing level or lower them, thus, benefiting the consumer. The benefit to each group concerned would vary depending upon many factors, some of which remain as subjects for further research. 


\section{Summary}

\section{The Problem}

The patterns of fluid milk distribution have been changing over the past twenty years with increasing emphasis on store sales. Unless retail milk delivery continues to become more efficient it may be priced out of the available market and be replaced by wholesale distribution. One proposal for increasing the efficiency of retail home delivery has been to reduce the frequency of delivery from the predominant three deliveries per week to a twice-weekly delivery basis.

The problem in this study was to determine if reducing the frequency of delivery from three times a week to twice a week had any significant effect upon the quantity of products delivered to retail route customers, the attitudes of consumers and distributors toward less frequent delivery, and to determine the relative cost of delivery, per unit, based upon trequency of delivery.

The purchases by all home delivery customers served by Johnson's All Star Dairy in Ashland, Kentucky, were tabulated for one complete week in October for each of three years-1958, 1959, and 1960. The data were later classified according to whether the customer purchased milk on a home-delivery basis during one, two, or all three of the years examined.

Analysis of variance and Duncan's New Multiple Range Test were used to test for a statistically significant relationship between the year in which two deliveries per week were offered (1959), and the years in which three deliveries per week were offered (1958 and 1960). The hypotheses were tested at the .05 level of probability.

\section{Experience with Twice-Weekly Delivery}

A total of 735 customers received retail home delivery from Johnson's All Star Dairy during the three-year period studied. These three-year customers purchased approximately 48 per cent, 60 per cent, and 65 per cent of the total milk delivered retail by this dairy during 1958, 1959, and 1960, respectively.

The three-year customers purchased 6,595 quart equivalents of fluid milk on home delivery routes during the week studied in 1958. During the selected week in 1959, when the company operated on a twiceweekly delivery basis, these same customers purchased 6,494 quart equivalents on home delivery, or a decrease of 1.5 per cent from 1958. In 1960 , when the company again offered three deliveries per week, the threeyear customers purchased only 6,299 quart equivalents of fluid milk during the selected week or a decrease of 3 per cent from 1959. However, analysis of variance and Duncan's New Multiple Range Tests indicated 
that neither of these decreases was significant at the .05 level of probability. It was also noted that national per capita consumption of fluid milk declined 1.7 per cent from 1958 to 1959 and an additional 1.5 per cent from 1959 to 1960.

Quantities of homogenized milk, regular milk, buttermilk, and chocolate milk purchased on retail home delivery routes by the three-year customers decreased from 1958 to 1959 and they also decreased from 1959 to 1960. However, the quantity of skim milk purchased by the three-year customers increased by 39.67 per cent and 40.23 per cent during the respective time periods. These data indicate that consumers' tastes and preferences are changing toward an increased usage of low-fat fluid milk although these products were still a relatively small part of total milk sales for the dairy studied.

The average price per unit of fluid milk delivered to the three-year customers increased during each time period examined. During the period of the twice-weekly delivery service the weighted average price per quart equivalent delivered was 26.2 cents compared with 25.6 cents per quart equivalent during the previous year. This was an increase of 2.3 per cent. During the year following the twice-weekly delivery experience, the average price per quart equivalent was 27.1 cents or an increase of 3.2 per cent above the 1959 average price.

Total revenue from home-delivered fluid milk sales to the three-year customers increased by 0.8 per cent from 1958 to 1959 , but by only 0.1 per cent from 1959 to 1960 .

Analysis of variance and Duncan's New Multiple Range Tests indicated that neither the increases in average price nor the increases in total revenue were significant at the .05 level of probability.

Johnson's Dairy also delivered products other than fluid milk on its retail home delivery routes. These additional products accounted for 2.9 per cent of the total quantity of all products delivered to the three-year customers in 1958, 3.4 per cent in 1959, and 3.6 per cent of the total in 1960.

During the selected week in 1959 , with the twice-weekly delivery service, the three-year customers purchased 17.8 per cent more additional products than they had purchased during the selected week in the previous year when three deliveries per week were offered. When the dairy reverted to three deliveries per week in 1960, purchases of additional products by the same customers increased by an additional 1.8 per cent. However, analysis of variance and Duncan's New Multiple Range Tests indicated that neither increase was significant at the .05 level of probability.

From 1958 to 1959 the average price per unit of additional products delivered decreased by 5.2 per cent. This decrease was due largely to the 
addition of margarine and half and half to the products sold. Both of these products were low priced relative to the remainder of the products which were offered on the home delivery routes.

During 1960, when three deliveries per week again were offered, the average price of all additional products delivered was 12.2 per cent greater than the average under twice-weekly delivery.

Total revenue received from the sale of additional products increased by 11.6 per cent from 1958 to 1959 , and again by an additional 14.2 per cent from 1959 to 1960.

Results of this study showed that the quantity of fluid milk delivered to the three-year customers decreased by a nonsignificant amount during each of the time periods examined, and the quantity of additional products delivered increased by a nonsignificant amount during the corresponding time periods. However, since the quantity changes were moving in opposite directions, they partially oftset each other, leaving less than a 1 per cent decrease in the total quantity of all products sold to the threeyear customers when the dealer converted from three deliveries per week in 1958 to only two deliveries per week in 1959.

The average price per unit for all products delivered to the threeyear customers increased by 2.3 per cent from 1958 to 1959 , and increased by an additional 3.8 per cent from 1959 to 1960. Total revenue received from the sale of all home delivered products to the three-year customers, increased by 1.3 per cent and 0.9 per cent during the corresponding time periods.

A review of previous delivery cost studies showed that delivery labor and truck costs accounted for approximately 50 per cent of the total marketing costs, and over 90 per cent of the total selling and delivery costs.

Delivery labor cost consisted largely of routemen's wages and varied depending upon the plan used to pay the routemen for their services. Truck costs were divided into fixed and variable costs with depreciation and gasoline costs accounting for the largest proportion of fixed costs and variable costs, respectively.

\section{Consumer Attitudes and Opinions}

In general, twice-a-week delivery was not acceptable among home delivery customers in either market studied. Fifty-eight per cent of the respondents indicated that they would not accept twice-a-week milk delivery while 21 per cent indicated acceptance. Also, another 21 per cent of the respondents already were getting delivery less than three times a week. Altogether, 58 per cent were opposed to twice-a-week delivery while 42 per cent would accept less frequent milk delivery. 
The principal reason given for refusing twice-a-week delivery was that customers believed that they could not maintain milk delivered so infrequently in fresh condition. This reason was indicated by 56 per cent of the respondents who were unwilling to accept the change. On the other hand, only 4 per cent of the 1,004 respondents had experienced trouble with milk keeping quality during the previous year, Also, 94 per cent of the 148 respondents who were receiving milk deliveries less than three times a week indicated that they had experienced no trouble with the keeping quality of this milk.

A Maine study found that milk flavor would be classed very good under twice-a-week milk delivery. Weese and Fike found that pasteurized milk and pasteurized-homogenized milk, when stored under home conditions, in West Virginia, maintained a flavor score of good or higher, and that it was in a usable condition after six days following delivery.

Sixteen per cent gave "prefer the present method" as a reason for non-acceptance. Evidently these people maintained a certain conservative reaction toward making changes, since no tangible reason was stated for opposing twice-a-week delivery. Perhaps their personal preferences could be altered by suitable promotion or experience with twice-a-week delivery.

A change from three times-a-week milk delivery to twice-a-week delivery would increase the need for milk storage space in home refrigerators. However, contrary to the authors' earlier beliefs, and expressions of milk distributors, lack of storage space was not found to be a major factor for customers' refusal of twice-a-week delivery. Thirteen per cent of the respondents who received home delivery indicated lack of storage space as a reason for non-acceptance of twice-a-week delivery. On the other hand, only 7 per cent said that they could not store 1.5 times their customary largest day's supply at any one time. Also, there was no significant difference between the amount of storage space available and acceptance or rejection of twice-a-week delivery. Thus, size of refrigerator did not appreciably influence customers to accept or reject twicea-week delivery.

It was also discovered that 85 per cent of the home-delivery customers interviewed would need to purchase only three quarts of milk or less each delivery day to make the change to twice-a-week delivery. Ninety-eight per cent would need only six quarts or less to make the change.

Other findings concerning customer milk buying opinions and attitudes were as follows:

Only 10 per cent of the respondents who were receiving home delivery indicated a willingness to pay over three cents per quart above store prices for such delivery. Twenty-nine per cent would pay up to one 
cent per quart, while 31 per cent would pay two cents per quart for home delivery. Twenty-one per cent would pay three cents per quart while 9 per cent of the respondents did not answer this question.

The neighborhood grocery was the most popular non-delivery retail source for milk. Forty-nine per cent of the home delivery customers were obtaining milk at neighborhood groceries while 42 per cent bought milk at supermarkets. The proportion making purchases at neighborhood groceries might indicate that families were making special trips to a store for milk.

Most home delivery customers did not purchase or desire to purchase products other than fluid milk through home delivery. Further sales promotion in "side-line" dairy products might make home delivery a more lucrative enterprise.

The data obtained in the two market areas, Ashland (the trial city) and Wheeling (the control city) indicated that there was little positive evidence that the trial of twice-a-week delivery in Ashland had appreciably affected milk buying habits of customers in that area.

There was a much higher percentage of customers receiving home delivery in Wheeling than in Ashland, but this difference may have been caused by the relatively large price differential between home delivery and store purchases of milk in Ashland.

Another difference between the two market areas was that in Ashland, as size of family increased, the proportion of delivered milk purchased per capita decreased, and the proportion of store purchases increased. In Wheeling the reverse conditions existed. However, this difference may have been caused by a combination of the price differential previously mentioned and a volume discount granted to some families in Wheeling for home delivered milk.

The amount of weekly income received per family did not affect respondents' decisions about obtaining home delivery. In fact, only a slightly lower percentage of low-income families (less than $\$ 100$ per week) received home delivery than high-income families ( $\$ 100$ or more per week). Evidently low-income families were about as willing to pay for the convenience of home delivery as were high-income families.

\section{Distributor Attitudes and Opinions}

Forty-seven milk processor-distributors reported that 44 per cent of their sales were made as retail deliveries to homes. Of those who had experienced a change in the proportion of their sales made at retail, approximately two-thirds indicated that retail route sales had declined relative to wholesale sales. The most frequently mentioned reason given for the decline in retail route sales was the convenience and availability 
of retail stores, particularly supermarkets, and the aggressive selling of supermarkets, including using milk as a "loss-leader" item.

Delivery by processor-distributors was predominantly on the basis of three deliveries per week with 52 per cent of 377 routes delivering on this basis. Thirty-seven per cent of the routes operated on a five-day basis, with one group of customers receiving deliveries three times per week and another group receiving twice-a-week delivery.

Although 73 per cent of the retail routes were scheduled to make three deliveries per week, only 71 per cent of the route customers received delivery at this frequency. However, 74 per cent of the total route volume was delivered using the three-deliveries-per-week system. The proportion of route operations and actual customer deliveries on a twicea-week basis were almost identical at 18 per cent but only 15.5 per cent of the retail volume was delivered at this frequency.

Thirteen of the 47 processor-distributors believed that reducing delivery to the twice-weekly basis would be feasible but only one of six producer-processor-distributors shared this view.

The reason most frequently mentioned by the distributors for the unfeasibility was the customers' lack of home storage space. Almost as many distributors believed that a shift to twice-a-week delivery would result in the loss or destruction of their retail sales.

Sixty per cent of the distributors believed that some customers could be served twice weekly while the remaining 40 per cent thought that no customer volume was low enough to permit this degree of reduction in service.

None of the 53 distributors interviewed had plans to shift exclusively to twice-weekly deliveries at the time they were interviewed. Forty-five per cent had never considered such a plan, and 28 per cent had considered or experimented with the plan but were not intending to use it.

Prior studies indicated that from one to one and three-tenths cents per quart equivalent could be saved by reducing the frequency of delivery from three days per week to two days per week. The amount of savings and the cost of delivering a unit of milk on a retail home delivery route varies depending upon locality and the costs applicable in the locality, including the plan used in paying the routeman for his services. 
